\title{
Tax evasion, minimum wage noncompliance, and informality
}

Article

Accepted Version

Basu, A. K., Chau, N. H. and Siddique, Z. (2012) Tax evasion, minimum wage noncompliance, and informality. Research in Labor Economics, 34. pp. 1-53. ISSN 0147-9121 doi: https://doi.org/10.1108/S0147-9121(2012)0000034004 (special issue 'Informal employment in emerging and transition economies') Available at https://centaur.reading.ac.uk/31303/

It is advisable to refer to the publisher's version if you intend to cite from the work. See Guidance on citing.

To link to this article DOI: http://dx.doi.org/10.1108/S0147-

9121(2012)0000034004

Publisher: Emerald

All outputs in CentAUR are protected by Intellectual Property Rights law, including copyright law. Copyright and IPR is retained by the creators or other copyright holders. Terms and conditions for use of this material are defined in the End User Agreement.

www.reading.ac.uk/centaur

\section{CentAUR}


Central Archive at the University of Reading

Reading's research outputs online 


\title{
Tax Evasion, Minimum Wage Non-Compliance and Informality*
}

\author{
Arnab K. Basu ${ }^{\dagger} \quad$ Nancy H. Chau ${ }^{\ddagger} \quad$ Zahra Siddique ${ }^{\S}$
}

This version: December 2011

\begin{abstract}
We study the impact of tax and minimum wage reforms on the incidence of informality. To gauge the incidence of informality, we use measures of the extent of tax evasion, the extent of minimum wage non-compliance, and the size of the informal workforce. Our approach allows us to examine (i) the distinction between determinants of firm-level reported wage distribution and actual wage distribution, (ii) the complementarity of tax and minimum wage enforcement, (iii) the impact that a minimum wage reform has on tax and minimum wage compliance, and (iv) the impact that a tax policy reform has on tax and minimum wage compliance. We conclude with the design of optimal minimum wage and tax policies (even in the complete absence of minimum wage enforcement). We do so based on two objectives derived from popular concerns associated with an unchecked expansion of informality: tax revenue maximization, and poverty alleviation among workers.
\end{abstract}

JEL Classification: J3, J6, O17.

Keywords: Tax evasion, Minimum Wage Reform, Flat Tax Reform, Poverty, and Informality

${ }^{*}$ We are grateful to Hartmut Lehmann for encouraging us to write this paper.

${ }^{\dagger}$ Department of Economics, College of William and Mary, Williamsburg, VA 23187. Email: akbasu@wm.edu

${ }^{\ddagger}$ Charles H. Dyson School of of Applied Economics and Management, Cornell University, Ithaca, NY 14853. Email: hyc3@cornell.edu

${ }^{\S}$ Institute for the Study of Labor, Bonn, Germany. Email: siddique@iza.org 


\section{Introduction}

What determines the incidence of informality? The answer clearly depends on how one defines informality. Within the development literature there are two different perspectives on how one defines informality, each focusing on causality going from government regulations to informality as a market response (Schneider and Enste 2000, Perry et. al. 2007).

The first perspective takes informality as an involuntary state of employment in a segmented labor market. Good jobs in the formal sector, characterized by regulated wages and benefits, are in high demand but short supply (Harris and Todaro 1970, Fields 1975, Chandra and Khan 1993). Rooted in the labor market implications of informality, therefore, informality (according to this perspective) refers to

"workers, particularly the old and young, who would prefer a job with standard labor protections, but are unable to get one." (Perry et. al. 2007, pp. 21.)

Associated with this perspective are measures of informality based on labor standards compliance. Such measures aim at capturing the coverage of workers by mandated labor protections such as the minimum wage (Saavedra and Chong 1999). Table 1 provides some examples of such informality measures as: (i) the share of workers not covered by social security contributions (based on 2007 and 2008 EU-SILC), (ii) the share of workers not covered by an employment contract (based on the European Social Survey 2008) and (iii) the share of workers not covered by social protection (OECD 2009). From Table 1, there is substantial variation across countries in the degree of informality, irrespective of the specific measure used. If one focuses on measure (iii) which gives the share of workers not covered by social protection, then informality characterizes close to or more than $50 \%$ of workers in nearly all the countries for which this measure is available.

A second perspective takes informality as a voluntary firm-level response to evade taxes and other costly regulations (De Soto 1989, Friedman et al. 2000, Djankov et al. 2002, Loayza, Serven, and Oviedo 2005, Schneider 2005, de Paula and Scheinkman 2010), when weak or non-existent enforcement of taxes and other costly regulations make informal operations more lucrative than formal regulated operations. Rooted in the public finance implications of informality, therefore, informality (according to this perspective) refers to

"firms and individuals avoiding taxation or other mandated regulations because everybody else does, and because enforcement is weak and uneven" (Perry et. al. 2007, pp. 22.)

Associated with this perspective are measures of informality based on tax compliance. Such measures may result from tax audits that define the magnitude of the informal economy as the 
difference between the income declared in tax returns and the income actually found after an audit (World Bank 2011). Table 2 provides examples of such informality measures, including measures that capture different shades of informality even among formally registered firms: (i) the percentage of firms expressing that a typical firm reports less than $100 \%$ of sales for tax purposes, (ii) the percentage of firms competing against unregistered or informal firms, (iii) the percentage of firms formally registered when they started operations in the country and (iv) the average number of years firms operated without formal registration. From Table 2, there is (as in Table 1) substantial variation across countries in the degree of informality, irrespective of the specific measure used. For example, if one focuses on measure (i), then Liberia ranks particularly high with respondents putting the percentage of firms which report too few sales to escape taxes as more than $97 \%$ while for Jordan this fraction is just $13 \%$. Moreover, measure (ii) shows a higher degree of informality for each country than does measure (iii).

These two distinct perspectives on informality have also inspired a large subsequent literature on theoretical modeling, as well as empirical policy analyses. In terms of theoretical modeling, the seminal work of Fields (1975) and related subsequent studies address formal and informal labor market consequences of formal sector wage regulations. Early studies are in the tradition of dualistic labor market models (Fei and Ranis 1964, Harris and Todaro 1970, Doeringer and Piore 1971, Stiglitz 1974), while recent studies relax assumptions on competitive labor markets (Basu, Chau and Kanbur 2010), and contractual commitments (Basu, Chau and Kanbur 2011). Models of tax evasion incorporating both an above- and an under-ground sector (Kesselman 1989, Jung, Snow and Trandel 1994) have also been developed. These models extend the traditional tax evasion frameworks of Allingham and Sandmo (1972) and Yitzhaki (1974) to a multi-sector setting and provide an analytical basis for ongoing debates concerning the role of tax policy reforms on tax evasion among formal firms, as well as the underground informal economy.

In terms of empirical policy analysis, there has been a recent surge in empirical research generating the following set of intriguing insights about how the informal economy operates in response to labor and tax regulations:

- minimum wage non-compliance is widespread among formal sector employers, as well as informal sector employers (Ashenfelter and Smith 1979, Lemos 2004, 2006, Gindling and Terrell 1995, 2006, Maloney and Nunez 2004);

- tax evasion is widespread among formal sector firms, as well as informal sector firms (Feige 1989, Tanzi 1980, 1999, Cowell 1990, Cobham 2005, Fuest and Riedel 2009);

- subminimum wages and informal employment can exhibit a diverse set of responses to minimum 
wage hikes (Card and Krueger 1995, Lemos 2004, Baanante 2004, Strobl and Walsh 2001);

- tax policy reforms can have a significant impact on the incidence of informality in an economy (Gabrielli, Galvao and Montes-Rojas 2011, Jonasson 2001, Koettl 2011, Slonimczyk 2011).

Given the above, the point of departure of this paper from existing literature is to provide a theoretical framework better equipped at capturing the realities that (i) both formal and informal firms may fail to comply with labor and tax regulations, while (ii) labor and tax regulations jointly determine the differing shades of informal firm like behavior through minimum wage non-compliance and tax evasion.

We posit a framework wherein formal establishments are subject to three sets of costs not borne by informal firms. With respect to wage regulation, formal establishments are expected to pay workers at least a minimum wage. With respect to tax regulations, formal establishments are obliged to pay authorities a tax on profits earned, and to withhold taxes on wage income to be transferred directly to authorities. With respect to the cost of entry, formal firms incur a cost of registration. In contrast, informal establishments and informal workers are free from both the state mandated regulation on wages and the need to pay taxes on profits or wages while operating in an environment where entry and exit is cost-free.

Firms must choose between operating in the formal or the informal sector, while workers seek wage protection in the formal sector (subject to wage income tax) using the informal wage as a reservation wage. Within this context, we examine three items of interest: (i) tax evasion via the misreporting of wage cost by formal firms, (ii) minimum wage non-compliance via the underpayment of the state mandated minimum wage among formal firms, and (iii) the incidence of informality as establishments choose to operate either in the formal or the informal sector.

In doing so, the contributions of this paper are the following. First, and to the best of our knowledge, this is the first attempt at examining minimum wage non-compliance by simultaneously scrutinizing the endogenous determinants of the reported wage cost of a formal employer and the actual take-home wage of a formal employee, in a setting where tax and minimum wage enforcement are both imperfect. A clear distinction between the two can offer important insights into empirical studies of wage distributions based either on firm-reported data on wage costs, or on labor force surveys from which records of actual take home wage can be ascertained. In particular, it is by now well-known that empirical studies of wage distributions in developing countries exhibit spikes at or around the minimum wage, despite lax enforcement. Our analysis provides the rationale for researchers to go one step deeper, to distinguish between reported wage distribution and actual wage distribution. For example, is the spike purely a reflection of a lip-service reporting of firm-level wage 
cost? Or is the true take home wage distribution of formal employee also marked by a spike at or around the minimum wage despite lax enforcement?

Second, the proposed model allows for a side-by-side comparison of tax compliance among formal employers, minimum wage compliance among formal employers, and the incidence of informality where neither tax regulations nor minimum wage regulations are fully respected. This is of particular importance for, in practice, tax enforcement in the formal sector is carried out via tax audits and random checks by tax authorities (Andreoni, Erard and Feinstein 1998), while minimum wage enforcement in the formal sector is carried out independently by labor inspectors (Weil 2004). An understanding of how tax enforcement directly impacts tax evasion, alters minimum wage noncompliance, and changes the overall incidence of informality is clearly key to effective formation of tax and wage enforcement policies. ${ }^{1}$

Third, our model provides a setting in which the potential direct and cross-cutting impacts of wage and tax policies on various measures of informality can be better understood. For example, how does a minimum wage hike impact the extent of tax evasion by formal firms, and the number of firms that completely do away with the obligation to pay taxes as they exit the formal sector? In this regard, we present a list of testable hypotheses that complement a series of papers dedicated to understanding minimum wage non-compliance (Ashenfelter and Smith 1979, Basu, Chau and Kanbur 2010) without the additional complication of tax evasion. Next, how does a tax reform impact the extent of minimum wage compliance by formal firms, and the number of firms that completely evade the obligation to pay a minimum wage by exiting to the informal sector? In this latter regard, we provide results that will substantially extend those of an earlier literature on tax evasion, for example, in which one or both of the following are absent: the minimum wage mandate, and the existence of an informal sector where tax obligations and minimum wage protection do not apply (Yaniv 1988, 1990, Tonin 2011).

The model we posit allows us to identify six distinctive potential regimes of labor market equilibria and as many potential sets of comparative statics responses of labor market outcomes with respect to changes in minimum wage and tax policies, depending on the pairing of minimum wage and worker productivity, as well as the nature of the tax and minimum wage policies. These embody

\footnotetext{
${ }^{1}$ The literature on the determinants, duration, and separation probability of formal employment, informal employment, and unemployment is a much better researched topic. On the duration, separation probabilities, and entry probabilities of formal and informal employment in Brazil, Argentina and Mexico, see Bosch and Maloney (2011). Almeida and Carneiro (2011) studies the impact of labor standards enforcement on mandated benefits on formal employment, informal employment and unemployment in Brazil. Chong, Galdo, Saavedra (2008) considers the role of labor legislations and worker productivity on the incidence of informality in Peru. Fugazza and Jacques (2004) theoretically examines the role of unemployment benefits, minimum wage, taxation and audits on labor allocation in a matching model. In a search theoretic setup, Albrecht, Navaroo and Vroman (2009) examines the role of labor market policy on the incidence of informality and the distribution of wages across formal-sector workers.
} 
combinations of cases where in equilibrium, (i) reported employer wage payment to government tax authorities exactly comply with, or exceed the official minimum wage, coupled with (ii) actual employer wage payment to workers that does not comply, complies exactly, or over-complies with the minimum wage law. In this paper, we make a complete characterization of the six classes of labor market equilibria and the corresponding comparative statics responses.

To pick one case in point, for minimum wages that are sufficiently high relative to worker productivity, strictly positive but imperfect tax enforcement, and no minimum wage enforcement, all employers report the exact payment of the minimum wage as required by law, but in truth evade taxes as the reported wage cost is an over-statement of wage that workers take home. Since tax evasion (or, wage understatement) is synonymous with minimum wage non-compliance (or, paying less than the reported minimum wage) here, the gap between the minimum wage and the actual wage is determined only by the strength of tax enforcement in place. Consequently, at constant tax enforcement, raising the minimum wage raises the reported wage as well as the actual wage dollar for dollar even in the complete absence of directly minimum wage enforcement, leaving the gap between the two constant. This suggests intriguingly that even when there is no minimum wage enforcement, the observed reported wage distribution exhibits a spike at the minimum wage, while the actual wage payment also exhibits a spike at a wage relative to the official minimum wage determined by the strength of tax enforcement that is in place.

Making use of the rich array of possible equilibrium outcomes and comparative statics responses characterized here, we draw three broad set of conclusions illustrating the direct and cross-cutting effects of four policy instruments - the tax rate on profit, the tax rate on personal income, the minimum wage, and the strength of tax enforcement - respectively on informal employment, tax evasion and minimum wage compliance. Specifically, we find that across all regimes of interest, and regardless of the size of the minimum wage relative to labor productivity, informal sector employment is weakly increasing in the four policy instruments. These follow directly from the weakly decreasing relationships between formal sector profit and respectively the two tax rates, the minimum wage, and the strength of tax enforcement, and the resulting weakly negative impact these policies have on job creation in the formal sector.

Contrasting the uniformity in the direction of informal employment response to the four policies, we find that the effectiveness of the four policies in combatting tax evasion differ sharply, depending critically on the height of the minimum wage relative to worker productivity. Suppose that the minimum wage is sufficiently low that in fact employers report a wage cost that exceeds the official minimum wage. Tax evasion here purely reflects employers' incentive to take full advantage of the gap between the profit tax and the personal income tax, adjusted for the strength of tax enforcement, 
to maximize post tax profits by under-reporting wage cost. Thus, raising the profit tax stimulates tax evasion, while raising the personal income tax, or the strength of tax enforcement discourages it. However, if the minimum wage is sufficiently high, we find that profit maximizing employers no longer report over-compliance with the minimum wage, but rather they maximize profits by reporting the exact payment of the minimum wage. The distance between this reported wage and the actual take home wage - the extent of tax evasion - naturally depends only on the strength of the tax enforcement in place. Thus, in sharp contrast to the case with low minimum wages, tax evasion here is fully independent of the two tax rates, and strictly decreasing in the strength of tax enforcement.

The effectiveness of the four policies in combatting minimum wage non-compliance is likewise critically dependent on the height of the minimum wage. With a sufficiently high minimum wage, as discussed the reported wage coincides with the minimum wage. As such, tax evasion becomes synonymous with minimum wage non-compliance. Since tax evasion depends only on the strength of tax enforcement in this case as discussed above, the same is true of minimum wage non-compliance. If, however, the minimum wage is sufficiently low, employers report over-compliance with the minimum wage. This severs the direct link between tax evasion and minimum wage non-compliance. Indeed, while tax evasion depends critically on the profit tax rate and the strength of tax enforcement, minimum wage compliance is wholly independent of these considerations.

The model concludes with a formulation of two sets of optimal wage and tax policies, respectively with the stated objective of poverty minimization, and tax revenue maximization, taking as given the strength of minimum wage and tax enforcement. These two objectives echo popular concerns regarding the consequences of runaway expansion of the informal sector. We show that the existence of a poverty alleviating minimum wage depends critically, among other things, on the strength of the tax enforcement regime, when minimum wage enforcement is lax. Meanwhile, we show that a flat tax reform can be justified, requiring the harmonization of the tax on profits and tax on wage income, on the grounds of tax revenue maximization, so long as corresponding adjustments in the minimum wage can be made as well.

The plan of this paper is as follows: In Section 2, the decision problem of a formal sector employer with respect to what wage to report to tax authorities, what actual wage to pay workers, and whether or not to exit to the informal sector will be established. In Section 3, the implied determinants of equilibrium tax evasion, minimum wage non-compliance, and incidence of informality will be examined. In Section 4, we provide an analysis of the optimal policy for poverty alleviation for a given poverty line, and finally in section 5, we provide an analysis of the optimal policy for tax revenue maximization. Section 6 concludes with suggestions for a number of directions for future research. 


\section{The Model}

\section{Workers}

We consider a labor market with a large pool of workers $(\bar{N})$. Each worker is distinguished by his skill level, $a \geq 0$, and the subset of skill type $a$ workers is given exogenously by $N(a)$. Two states of employment are available: informal sector employment, and formal sector employment. The informal sector is a free-entry sector: any worker that desires a job can find one there, and any worker that desires to exit the sector can do so at will. ${ }^{2}$ By contrast, we denote the endogenous likelihood that a skill type $a$ worker receives a formal sector job offer as $\alpha(a)$.

Formal sector workers are obligated to pay personal income tax, but informal sector workers are not. The corresponding formal and informal sector take-home earnings, net of any personal income tax withheld by employers in the formal sector $t_{f}(a)$, will be denoted as $\omega_{f}(a)-t_{f}(a)$ and $\omega_{i}(a)$ respectively. Conditional on receiving a formal sector job offer, a skill type $a$ worker compares $\omega_{f}(a)-t_{f}(a)$ with the reservation benchmark $\omega_{i}(a)$, and selects the best of the two. Otherwise, without a formal job offer, the worker earns $\omega_{i}(a)$ in the informal sector.

\section{Formal Employers}

Let there be an endogenous $M(a)$ number of employers in search of skill type $a$ workers in the formal sector. A match between an employer and a skill type $a$ worker in the formal sector generates net output $a .^{3}$ Formal employers are furthermore subject to a minimum wage legislation and a tax on profits, unlike informal sector employers who are free from these obligations. For any formal sector employer with a contracted worker, expected profit is given by the value of net output $a$ net of wage cost $\omega_{f}(a)$, adjusted for any required tax withholdings of labor earnings $t_{f}(a)$, applicable taxes $T(a)$ on wages and profits, and expected penalties associated with the discovery of tax evasion $\operatorname{Ep}(a)$, if any:

$$
\pi_{f}(a)=a-\left[\omega_{f}(a)-t_{f}(a)\right]-T(a)-E p(a) .
$$

\section{Matching in the Formal Sector}

The meeting of formal sector job seekers and formal sector employers is characterized by the presence of match friction in the formal labor market. Specifically, let $\Phi(M(a), N(a))=\theta M(a)^{\beta} N(a)^{1-\beta}, \beta \in$ $[0,1]$ denote a matching technology that gives the number of matches between employers and workers, given $M(a)$ number of formal employers with a job offer no worse than an informal job, and $N(a)$

\footnotetext{
${ }^{2}$ Though informal employment is modeled as wage employment here, the results of the our analysis will remain unchanged if informal self-employment is considered instead, when each self-employed informal sector worker receives a skill specific take home income of $\omega_{i}(a)$.

${ }^{3}$ Net output $a$ is taken to account for any other costs of production, associated with capital use for example, per worker hired.
} 
number of formal sector job seekers. As stated, $\Phi(\cdot)$ is increasing in both arguments, and homogeneous of degree one in $(M(a), N(a))$. The associated likelihood that an individual worker seeking employment is matched with a formal sector offer is

$$
\alpha(a)=\frac{\Phi(M(a), N(a))}{N(a)}
$$

while the likelihood that an employer seeking a worker is matched with one is

$$
\alpha_{e}(a)=\frac{\Phi(M(a), N(a))}{M(a)} .
$$

\section{Becoming a Formal Employer}

Denote the cost associated with registering a formal sector firm plus any additional cost required to raise start-up capital, for example, as $c_{f}$. Expected formal sector profit is thus:

$$
E \pi_{f}(a)=\alpha_{e}(a) \pi_{f}(a)-c_{f} .
$$

We now turn to employers in the informal sector. Many studies have argued that without formal registration, and without the ability to raise the startup capital that a formally registered firm is able to, a productivity gap exists between formal and informal firms (Loayza 1996, Djankov et al. 2003, Straub 2005, Amaral and Quintin 2006). We follow this line of argument and take the productivity of a worker in the informal sector to be only a fraction $w_{i}<1$ of his full productivity.

With perfect competition and free-entry on both the supply and demand sides of the informal labor market, expected profits in the informal sector $E \pi_{i}(a)$ are driven to zero,

$$
E \pi_{i}(a)=0
$$

while the informal wage is given by the marginal value of product of laborers there, $\omega_{i}(a)=w_{i} a$.

Armed with (1), (4) and (5), an employer makes a decision between operating in the formal and the informal sector by comparing $E \pi_{f}(a)$ and $E \pi_{i}(a)$. In equilibrium, employers are indifferent between the two sectors whenever

$$
E \pi_{f}(a)=E \pi_{i}(a) \Leftrightarrow \alpha_{e}(a) \pi_{f}(a)-c_{f}=0
$$

By definition of the likelihood of a match with a worker $\alpha_{e}(a)$ in (3), and the likelihood of formal job arrival facing workers $\alpha(a)$ in $(2)$,

$$
\alpha_{e}(a)=\frac{c_{f}}{\pi_{f}(a)}, \text { and } \alpha(a)=\theta^{1 /(1-\beta)}\left(\frac{\pi_{f}(a)}{c_{f}}\right)^{\beta /(1-\beta)} .
$$

It follows from (6) that in order to ascertain the likelihood of equilibrium formal sector employment, $\alpha(a)$, or that of equilibrium informal sector employment, $1-\alpha(a)$, information about after-tax profits of employers of skill type $a$ workers, $\pi_{f}(a)$, is paramount. We turn to a detailed analysis of $\pi_{f}(a)$ now. 


\subsection{Tax Evasion, Minimum Wage, and Expected Formal Profits}

The decision problem of a formal employer is two-fold: choose a wage $r(a)$ to be reported to tax authorities based on which the formal employer's tax liability will be assessed, and an actual wage $\omega_{f}(a)$ to be paid to workers that need not be equal to $r(a)$. Whenever $r(a)>\omega_{f}(a)$, we say that there is over-reporting of wage cost. Otherwise, if $r(a)<\omega_{f}(a)$, we say that wage cost is under-reported. ${ }^{4}$

Let $\tau_{\omega}<1$ denote the personal income tax rate. Formal employers are required to withhold taxes on labor income and transfer them directly to tax authorities. Thus, an employer's choice of reported wage cost $r(a)$ will have a direct bearing on the amount of tax withholdings from labor income, for tax withholding is given simply by the personal income tax rate multiplied by the reported wage $r(a)$ :

$$
t_{f}(a)=\tau_{\omega} r(a) .
$$

To ensure that formal sector employment is viable, in that the post-tax income of a formal sector worker can exceed that of an informal sector worker, we work with parameter values such that $a\left(1-\tau_{\omega}\right)$ exceeds $w_{i} a$, or $1-\tau_{\omega}-w_{i}>0$, requiring effectively that the post-tax net output that each formal worker can generate exceeds the informal sector counterpart.

Denote $\tau_{\pi}<1$ as the profit tax rate. For a formal employer, the total amount of taxes due to tax authorities, calculated based on reported wage cost $r(a)$, is given by $\tau_{\pi}$ times pre-tax reported profit $(\min \{0, a-r(a)\})$, plus personal income taxes withheld $\left(\tau_{\omega} r(a)\right)$ :

$$
T(a)=\tau_{\pi} \min \{0, a-r(a)\}+\tau_{\omega} r(a)
$$

where $\tau_{\pi} \min \{0, a-r(a)\} \geq 0$ indicates a tax policy that does not provide subsidies to employers who reportedly earn negative pre-tax profits.

Henceforth, let $\phi(a)$ denote the likelihood of a tax audit. With probability $1-\phi(a)$, the formal employer is not audited, and profit is simply given by net output $a$, net of wage cost adjusted for personal income taxes withheld $\left(\omega_{f}(a)-\tau_{\omega} r(a)\right)$, and net of profit tax due to authorities calculated based on reported wage cost $\left(\tau_{\pi} \min \{0, a-r(a)\}+\tau_{\omega} r(a)\right)$ :

$$
a-\omega_{f}(a)-\tau_{\pi} \min \{0, a-r(a)\}
$$

As may be expected, given the true wage cost $\omega_{f}(a)$, formal employer profit rises with the reported wage $r(a)$ since $r(a)$ is inversely related to a formal employer's calculated tax liability $\tau_{\pi} \min \{0, a-$ $r(a)\}$.

\footnotetext{
${ }^{4}$ We focus here exclusively on the possibility of tax evasion based on the mis-reporting of costs, and assume that revenue $a$ is verifiable upon audit. Other methods of tax evasion clearly exist. For example, in a setting where a firm employs multiple workers, under-reporting the number of workers is another interesting possibility. We thank a referee for pointing this out, and leave the issue for future research.
} 
With probability $\phi(a)$, the formal employer is audited. This leads to the discovery of the extent of mis-reported profits, if any. Let $p(a)$ denote the penalty associated with the discovery of mis-reported profits equaling $\left|\left[a-\omega_{f}(a)\right]-[a-r(a)]\right|=\left|r(a)-\omega_{f}(a)\right|$, and of mis-reported wage cost, also equal to $\left|r(a)-\omega_{f}(a)\right|$. Total penalty to be imposed on a tax evading employer, if discovered, will given by $\bar{p}$ multiplied by the extent of mis-reporting:

$$
p(a)=\bar{p}\left|r(a)-\omega_{f}(a)\right|
$$

$\bar{p}$ parameterizes the severity of the penalty associated with each dollar of mis-reported wages and profits $\left|r(a)-\omega_{f}(a)\right|$. Throughout we will assume that $\bar{p} \geq 1$ so employers must at least pay back to tax authorities that amount which is mis-reported when discovered. In the event of a tax audit, therefore, formal employer profit must now account for the penalty cost $p(a)$, and is given by:

$$
\begin{aligned}
& a-\omega_{f}(a)-\tau_{\pi} \min \{0, a-r(a)\}-p(a) \\
= & a-\omega_{f}(a)-\tau_{\pi} \min \{0, a-r(a)\}-\bar{p}\left|r(a)-\omega_{f}(a)\right| .
\end{aligned}
$$

We assume in what follows that the likelihood of a tax audit $\phi(a)$ is determined by the likelihood that a tax filing is red-flagged. We also assume that the criteria chosen by tax authorities to red-flag a tax filing are relevant, in the sense that the likelihood assigned to red-flag a tax filing rises with the extent of actual tax mis-reporting, $\left|\left(r(a)-\omega_{f}(a)\right)\right|$. These are plausible assumptions. For example, the Internal Revenue Service in the United States formulates and implements a "discriminant function" on each tax return. The results inform the construction of a "DIF score", which is used to determine the likelihood of tax audit. According to Andreoni, Erard and Feinstein (1998), over half of the tax audit selections in the United States are based at least in part on this score, and average tax assessments based on selections from the DIF score and other special examination initiatives are systematically higher than tax assessments generated by random audits. ${ }^{5}$ In view of these evidence, we assume henceforth that the likelihood of a tax audit is increasing in the extent of tax mis-reporting, and specifically,

$$
\phi(a) \equiv \bar{\phi}\left|r(a)-\omega_{f}(a)\right|
$$

$\bar{\phi}$ parameterizes the frequency of tax audits, for given mis-reporting of true tax liability $\left|r(a)-\omega_{f}(a)\right|{ }^{6}$

\footnotetext{
${ }^{5}$ In Danziger (2010) which studies the issue of minimum wage non-compliance, the probability of detection is taken to be strictly increasing in the number of workers hired, and independent of the extent of the minimum wage violation. In our setup where each employer hires one worker, the question of the endogeneity of inspection likelihood does not arise. As another alternative, $\phi(a)$ is a constant with random auditing. It can be easily verified that regardless of worker productivity, a corner solution applies - no employer ever evade taxes, or all employers evade taxes to the maximum extent possible. We thank two anonymous referees for pointing out these possibilities.

${ }^{6}$ Given this assumption on $\phi(a)$, we will check in what follows that upon substituting for the equilibrium employer choice of tax evasion $\left|r^{*}(a)-\omega_{f}^{*}(a)\right|$, where an asterisk denotes equilibrium values, the implied equilibrium likelihood of a tax audit $\phi(a)=\bar{\phi}\left|r^{*}(a)-\omega_{f}^{*}(a)\right|$ is a fraction in the [0,1] interval.
} 
It follows that expected formal employer profit is:

$$
\begin{aligned}
\pi_{f}(a)= & (1-\phi(a))\left[a-\omega_{f}(a)-\tau_{\pi} \min \{0, a-r(a)\}\right] \\
& +\phi(a)\left[a-\omega_{f}(a)-\tau_{\pi} \min \{0, a-r(a)\}-\bar{p}\left(r(a)-\omega_{f}(a)\right)\right] \\
= & a-\left[\omega_{f}(a)+\tau_{\pi} \min \{0, a-r(a)\}\right]-\bar{\phi} \bar{p}\left(r(a)-\omega_{f}(a)\right)^{2} .
\end{aligned}
$$

where the sum $\omega_{f}(a)+\tau_{\pi} \min \{0, a-r(a)\}$ gives the sum of wage cost net of taxes withheld and applicable taxes to be transferred to tax authorities $\left[\omega_{f}(a)-\tau_{\omega} r(a)\right]+\left[\tau_{\pi} \min \{0, a-r(a)\}+\tau_{\omega} r(a)\right]$ as shown in (1), and the expected penalty $E p(a)$ in (1) is given by $\bar{\phi} \bar{p}\left(r(a)-\omega_{f}(a)\right)^{2}$.

We are now in a position to formally examine the decision problem of a formal employer. In choosing $\omega_{f}(a)$ and $r(a)$ to maximize profits $\pi_{f}(a)$, we note that any formal employer faces two types of constraints:

\section{Participation Constraint}

The first constraint that formal employers must take note of accounts for workers' option to seek employment in the informal sector at any time. Thus, to attract workers, a formal job offer must be no worse than an informal job offer. Equivalently, the take home wage of a formal sector worker accounting appropriately for taxes withheld must be no less than the informal sector wage $\omega_{i}(a)=w_{i} a$ from (5). Furthermore, since taxes withheld is given by the tax rate $\tau_{\omega}$ times reported wage cost, the participation constraint is:

$$
\omega_{f}(a)-t_{f}(a) \geq w_{i} a, \Leftrightarrow \omega_{f}(a)-\tau_{\omega}(a) r(a) \geq w_{i} a .
$$

\section{Minimum Wage Constraint}

The second constraint that formal employers must also take note of accounts for the minimum wage legislation. In our context where actual and reported wages can differ, the minimum wage constraint requires that the employer must report at least the minimum wage as their per worker wage cost:

$$
r(a) \geq \bar{w} .
$$

A failure to do so is tantamount to a wilful disregard of the minimum wage legislation, and is taken to trigger an immediate audit and fines, large enough to obligate compliance with the reporting constraint. ${ }^{7}$ Beyond this requirement that constrains employers' reporting of wage cost, we focus in

\footnotetext{
${ }^{7}$ Of course, reporting the payment of the minimum wage does not guarantee the actual payment of such a wage. Ashenfelter and Smith (1979), for example, touches on the strategy of issuing a bonafide paycheck. Employers issue a pay check for the amount requirement by the minimum wage, and in exchange, extracts some value of the paycheck from workers. By contrast, Saget (2008) points out that there are countries in which payment of the minimum is optional rather than compulsory. This is the case in Indonesia for example where the minimum wage legislation lays out clearly exceptions that can be made for employers who are not able to pay the minimum wage. In our paper, we focus our analysis the case where the payment of the minimum wage is compulsory by law, and nonpayment of the minimum wage is illegal. We thank an anonymous referee for pointing this out.
} 
this paper on a government that completely turns a blind eye to the possibility of minimum wage non-compliance, among employers that reportedly pay the minimum wage. We do so to scrutinize the potential link between the frequency of tax audits and minimum wage compliance even in the complete absence of minimum wage enforcement, and also to account for the reality that minimum wage enforcement is far less than perfect in both developed and developing countries (Ashenfelter and Smith (1979), Basu, Chau and Kanbur (2009)). ${ }^{8}$

A number of observations are in order before we proceed any further. First, an employer's choice of $\omega_{f}(a)$ and $r(a)$ determines first and foremost the extent of tax evasion per worker employed as given by the difference:

$$
\left|r(a)-\omega_{f}(a)\right|
$$

A priori, it is not clear at all whether tax evasion should come in the form of over-reporting or under-reporting of wages. For one thing, we know from the definition of $\pi_{f}(a)$ in (9) that every dollar increase in reported wage cost raises employer profits by $\tau_{\pi}$ for given $\omega_{f}(a)$. But meanwhile, raising $r(a)$ decreases the take home income of formal sector workers. If the participation constraint in (10) binds, every dollar increase in reported wage cost $r(a)$ would require a corresponding increase in actual wage cost by at least $\tau_{\omega}$ dollars. These suggest that two sets of considerations should be expected to be in play in the employer's decision problem: (i) whether the participation constraint binds, and (ii) whether a tax gap exists between the profit $\tau_{\pi}$ and the personal income tax rates $\tau_{\omega}$.

Second, an employer's choice of $\omega_{f}(a)$ and $r(a)$ also determines the extent of minimum wage non-compliance. We gauge this non-compliance by evaluating the difference between the post-tax wage income of a minimum wage worker, $\bar{w}\left(1-\tau_{\omega}\right)$, and the actual wage income of the same worker net of taxes withheld and calculated based on the reported wage, $\omega_{f}(a)-\tau_{\omega} r(a)$ :

$$
\bar{w}\left(1-\tau_{\omega}\right)-\left[\omega_{f}(a)-\tau_{\omega} r(a)\right]
$$

If strictly positive, (12) gives the extent of minimum wage non-compliance. If strictly negative, there is over-compliance with the minimum wage legislation. Finally, if (12) is equal to zero, formal sector workers receive exactly the minimum wage net of any government mandated personal income tax evaluated based on the minimum wage as their take home earning. There are three open questions here, each requiring an in-depth analysis: (i) Are there systematic differences between reported wages $r(a)$ and actual take home wages $\omega_{f}(a)-\tau_{\omega} r(a)$ across workers of differing skill levels? In other words, how should reported minimum wage compliance be expected to compare with actual minimum wage compliance? (ii) How does the extent of minimum wage non-compliance respond to a hike in the

\footnotetext{
${ }^{8} \mathrm{~A}$ full account of a formal employer's decision problem in the presence of tax and minimum wage enforcement would require a full-length analysis that is beyond the scope of the current study. We leave this for future research.
} 
minimum wage when minimum wage enforcement is lax, but tax audit is carried out in regular frequency? (iii) What is the nature, if any, of the cross-cutting influence that changes in the tax rates may have on minimum wage non-compliance, or that changes in the minimum wage may have on the extent of tax evasion?

As a third observation, note that economy-wide tax evasion and minimum wage compliance depend not just on what formal sector employers do, but on the incidence of informal sector employment as well, since informal employers do not pay taxes, nor do they comply with the minimum wage law. From (6), the incidence of informality, as measured by the fraction of informal sector workers among skill type $a$ workers, is:

$$
1-\alpha(a)=1-\theta^{1 /(1-\beta)}\left(\frac{\pi_{f}(a)}{c_{f}}\right)^{\beta /(1-\beta)} .
$$

Thus, in order to ascertain the effectiveness of a minimum wage policy $\bar{w}$ in raising labor earnings beyond $w_{i} a$, and the effectiveness of the tax policy $\left\{\tau_{\pi}, \tau_{\omega}, \bar{\phi} \bar{p}\right\}$ in collecting tax revenue, the possibility that any policy shock can lead to a potential exodus of formal sector employers to the informal sector must be accounted for.

With these three considerations in mind, the ensuing analysis will focus on the role of four policy

measures $\left(\bar{w}, \tau_{\pi}, \tau_{\omega}, \bar{\phi} \bar{p}\right)$ on (i) tax evasion, (ii) minimum wage non-compliance and (iii) incidence of informality as defined above. Later on in Section 4, the optimal choice of minimum wage and tax policies to fulfill two distinctive goals: to maximize tax revenue, and to minimize the incidence of poverty, will be formally defined and examined.

\section{Tax Evasion, Minimum Wage Non-compliance and Incidence of Informality}

We undertake here an analysis of tax evasion, minimum wage non-compliance and the corresponding incidence of informality for the case where the minimum wage is less than the net output per worker in the formal sector: $a>\bar{w}$. The complementary case of $a<\bar{w}$ would of course trivially generate a complete exodus of formal sector employers to the informal sector if the minimum wage law is enforced. It can be demonstrated that the qualitative findings in what follows remain unchanged even in the imperfect enforcement case, and the proof is available upon request.

From (9), the decision problem of the employer is:

$$
\max _{\omega_{f}, r} a-\omega_{f}-\tau_{\pi} \min \{a-r, 0\}-\bar{\phi} \bar{p}\left(r-\omega_{f}\right)^{2}
$$

subject to the participation constraint $\omega_{f} \geq w_{i} a+\tau_{\omega} r$, and the minimum wage constraint $r \geq \bar{w}$. Denote the solutions to (14) with an asterisk, there are six possible regimes to consider: with strictly 
positive reported profits $a-r^{*}(a)>0$, (I) only the participation constraint is strictly binding, (II) only the minimum wage constraint is strictly binding and (III) both constraints are binding. ${ }^{9}$ The remaining three possible cases apply when reported profit $a-r^{*}(a)$ is non-positive, with (IV) only the participation constraint is strictly binding, (V) only the minimum wage constraint is strictly binding and (VI) both constraints are binding.

\subsection{Positive Reported Profits}

We begin with the case of positive reported profits, and consider each of the three regimes (I) - (III) alluded to above:

\section{Binding Participation Constraint}

For an employer who reports positive pre-tax profit, $\max \{a-r, 0\}=a-r$, and as such from (14) his decision problem is:

$$
\max _{\omega_{f}, r} a-\omega_{f}-\tau_{\pi}(a-r)-\bar{\phi} \bar{p}\left(r-\omega_{f}\right)^{2} .
$$

Maximizing the above subject to a binding participation constraint, $\omega_{f}-\tau_{\omega} r=w_{i} a$ the profit maximizing choices of a formal employer are: ${ }^{10}$

$$
r^{*}(a)=\frac{w_{i} a+\delta}{1-\tau_{\omega}}, \quad \omega_{f}^{*}(a)=\frac{w_{i} a+\delta \tau_{\omega}}{1-\tau_{\omega}}, \omega_{f}^{*}(a)-r^{*}(a) \tau_{\omega}=w_{i} a
$$

where $\delta \equiv\left(\tau_{\pi}-\tau_{\omega}\right) /\left[2 \bar{\phi} \bar{p}\left(1-\tau_{\omega}\right)\right]$. Intuitively, with the participation constraint strictly binding, formal sector workers take home their reservation wage $\omega_{f}^{*}(a)-\tau_{\omega} r^{*}(a)=w_{i} a$, and any increase in formal sector income tax $\tau_{\omega} r^{*}(a)$ must be compensated by a corresponding increase in pre-tax wage $\omega_{f}^{*}(a)$. In addition, from (15), the formal employer over-reports wage cost $r^{*}(a)>\omega_{f}^{*}(a)$, or equivalently $\delta>0$, if and only if the profit tax rate $\tau_{\pi}$ exceeds the personal income tax $\tau_{\omega}$, and under-reports wage cost $r^{*}(a)<\omega_{f}^{*}(a)$ otherwise when $\tau_{\pi}$ is less than $\tau_{\omega}$.

Table 3 displays separately the profit tax rates and the lowest personal income tax rates in 120 countries (World Bank 2011, PricewaterhouseCoopers 2011). ${ }^{11}$ We take the lowest personal income tax rate as the relevant income class for minimum wage workers. As shown, in an overwhelming majority of these countries where tax data is available, the profit tax rate strictly exceeds the

\footnotetext{
${ }^{9}$ It is straightforward to verify that for any $\left(\omega_{f}, r\right)$ pair such that neither of the two constraints bind, $\omega_{f}>w_{i} a+\tau_{\omega} r$ and $r>\bar{w}$, an alternative pairing $\left(\omega_{f}^{\prime}, r^{\prime}\right)$ can be found along a binding participation constraint that raises expected profit, $a-\omega_{f}-\tau_{\pi}(a-r)-\bar{\phi} \bar{p}\left(r-\omega_{f}\right)^{2}<a-\omega_{f}-\tau_{\pi}\left(a-r^{\prime}\right)-\bar{\phi} \bar{p}\left(r^{\prime}-\omega_{f}^{\prime}\right)^{2}$. A formal proof is relegated to Appendix A.

${ }^{10}$ In this, as well as in all of the subsequent maximization problems, it is straightforward to verify that the second order conditions are satisfied. In addition, from (15), the implied equilibrium likelihood of a tax audit $\phi^{*}(a)=\bar{\phi}\left(r^{*}(a)-\right.$ $\left.\omega_{f}^{*}(a)\right)=1 /(2 \bar{p})$ in regime $\mathrm{I}$ is in the interior of the $[0,1]$ interval since the penalty parameter $\bar{p}$ is assumed to take on values greater than or equal to unity.

${ }^{11}$ World Bank (2011) data is from 2010 survey (latest data available for 2011) and PricewaterhouseCoopers (2011) is also the latest available (accessed 2011).
} 
corresponding personal income tax rate. In view of this evidence, we will henceforth maintain the assumption that $\tau_{\pi}>\tau_{\omega}$, with the implication that formal employers will tend to over-report wage costs. Thus, $\left|r^{*}(a)-\omega_{f}^{*}(a)\right|=r^{*}(a)-\omega_{f}^{*}(a)$. This finding is intuitive, and consistent with Yaniv (1990) which analyzes the case without a minimum wage and without an informal sector. In particular, since the profit tax rate exceeds the personal income tax rate, under-reporting profits confers greater tax savings to the employer than under-reporting wage cost, when the post-tax take home income of formal workers cannot fall below the reservation level $w_{i} a$.

Tax evasion, in this case, depends critically on the tax gap $\tau_{\pi}-\tau_{\omega}$, in particular, from (15)

$$
r^{*}(a)-\omega_{f}^{*}(a)=\delta=\frac{\tau_{\pi}-\tau_{\omega}}{2 \bar{\phi} \bar{p}\left(1-\tau_{\omega}\right)}
$$

the larger the tax gap, the larger will be the equilibrium tax evasion. Furthermore, the frequency of tax auditing as parameterized by $\bar{\phi}$, and the penalty associated with discovered tax evasion $\bar{p}$, both mitigate against employer incentives to evade taxes. Small changes in the minimum wage do not alter the tax evasion calculation based purely on the tax gap and tax enforcement, and have thus no impact on equilibrium tax evasion.

From (15), minimum wage non-compliance is given by:

$$
\bar{w}\left(1-\tau_{\omega}\right)-\left(\omega_{f}^{*}-r^{*}(a) \tau_{\omega}\right)=\bar{w}\left(1-\tau_{\omega}\right)-w_{i} a .
$$

Clearly, formal employers of sufficiently high skilled workers, with $a>\bar{w}\left(1-\tau_{\omega}\right) / w_{i}$, over-comply with the minimum wage legislation for otherwise an informal sector job will be more attractive to workers. All other employers offer workers just enough to make a formal job attractive, though not enough to comply with the minimum wage mandate. For those that do not comply with the minimum wage legislation, since workers take home exactly their reservation income $w_{i} a$ in the presence of a binding participation constraint, the extent of minimum wage non-compliance is exactly equal to the difference between the government mandated take home wage $\bar{w}\left(1-\tau_{\omega}\right)$ and the reservation wage $w_{i} a$. It follows therefore that an increase in the government mandated minimum post-tax take home wage $\bar{w}\left(1-\tau_{\omega}\right)$ stimulates minimum wage non-compliance. Meanwhile, small changes in the profit tax $\tau_{\pi}$ has no impact on this minimum wage policy induced mandate to increase wages by $\bar{w}\left(1-\tau_{\omega}\right)-w_{i} a$, and thus have no impact on minimum wage non-compliance.

Now, substituting (15) into (13), and using (6), the incidence of informality $1-\alpha^{*}(a)$ is given by:

$$
1-\theta^{1 /(1-\beta)}\left(\left[\frac{1-\tau_{\pi}}{1-\tau_{\omega}}\left(a\left(1-\tau_{\omega}-w_{i}\right)\right)+\bar{\phi} \bar{p} \delta^{2}\right] / c_{f}\right)^{\beta /(1-\beta)} .
$$

Routine differentiation reveals that $1-\alpha^{*}(a)$ is increasing in both tax rates, and in the frequency and penalty associated with tax audits $\bar{\phi}$ and $\bar{p}$ if and only if the employer mis-reports the true wage 
cost, or if and only if $\tau_{\pi} \neq \tau_{\omega}$. Again since workers are paid their reservation wage, formal employer profits are in fact independent of the minimum wage $\bar{w}$. This is true for employers of highly skilled workers $a>\bar{w}\left(1-\tau_{\omega}\right) / w_{i}$ who over-comply with the minimum wage law, as well as those who do not comply $\left(a<\bar{w}\left(1-\tau_{\omega}\right) / w_{i}\right)$.

We now check the conditions under which our starting premises are true: that (i) the participation constraint is the only binding constraint, and that (ii) reported pre-tax profit $a-r^{*}(a)$ is strictly positive. From (15), the participation constraint is the only binding constraint if and only if formal employers report a wage greater than the minimum wage $r^{*}(a)>\bar{w}$. From (15), this occurs if and only if the minimum wage is sufficiently small relative to the productivity of the workers:

$$
r^{*}(a)=\frac{w_{i} a+\delta}{1-\tau_{\omega}}>\bar{w} \Leftrightarrow \bar{w}<\frac{w_{i} a+\delta}{1-\tau_{\omega}} .
$$

This is illustrated in Figure 1a. To the right of the 45 degree line are all combinations of $a$ and $\bar{w}$ such that worker productivity exceeds the minimum wage. The upward sloping schedule labeled PC furthermore divides all $(a, \bar{w})$ combinations into two groups. For those $(a, \bar{w})$ that lie below the PC schedule, the inequality in (17) holds, and as such, the participation constraint is the only binding constraint. Otherwise, for all other combinations that lie above the PC schedule, the inequality in (17) is violated as $\bar{w}$ is high enough now so that the minimum wage constraint starts to bind.

Furthermore, and also from (15), reported pre-tax profit is strictly positive if and only if $a>r^{*}(a)$, or equivalently, when worker productivity is sufficiently high:

$$
r^{*}(a)=\frac{w_{i} a+\delta}{1-\tau_{\omega}}<a \Leftrightarrow a>\frac{\delta}{1-\tau_{\omega}-w_{i}} .
$$

In Figure 1a, for all employer-worker matches involving $a \geq \delta /\left(1-\tau_{\omega}-w_{i}\right)$, and all $(a, \bar{w})$ to the right of the upward sloping schedule labeled PC, formal employers maximize profits by reporting positive profits, and by reporting a wage cost that strictly exceeds the minimum wage $\bar{w}$. To the left

of $a=\frac{\delta}{1-\tau_{\omega}-w_{i}}$, worker productivity is too small and formal employer maximize profits by reporting non-positive profits. We will return to this case in the sequel.

Summarizing, with high output per worker, $a>\delta /\left(1-\tau_{\omega}-w_{i}\right)$, formal employers report positive profits (from (18)). As long as there is a tax gap between profit and personal tax income $\tau_{\pi} \geq \tau_{\omega}$, over-reporting of wage cost occurs (from (15)). The extent of this mis-reporting depends importantly on the size of the tax gap, the frequency of tax audits and the associated penalty. For some employers in this range, particularly those with sufficiently high skilled workers, this over-reporting of wage cost occurs as they over-comply with the minimum wage legislation, and pay each worker more than what the minimum wage legislation mandates. Other employers in the range continue to over-report wage cost, but do not comply with the minimum wage legislation. Even accounting for 
wage over-reporting, however, in this range with relatively high worker productivity and relatively low minimum wage $\left(\bar{w}<\left(w_{i} a+\delta\right) /\left(1-\tau_{\omega}\right)\right)$, the participation constraint is binding, meaning that the post-tax take-home earnings of formal sector workers is equal to the reservation wage $w_{i} a$ (from (17)). It follows, therefore, that in the absence of minimum wage enforcement, the minimum wage is ineffective in the sense that the income well-being of workers in this range is in fact fully invariant to the minimum wage, as well as the two tax rates $\tau_{\pi}$, and $\tau_{\omega}$.

\section{Binding Minimum Wage Constraint}

Now, let us consider the case in which the minimum wage constraint is the only binding constraint. Here, formal employers report paying the lowest wage mandated by the minimum wage legislation at $r=\bar{w}$, while at the same time offer contracted workers a post tax take home wage that strictly exceeds their reservation wage $\omega_{f}-\tau_{\omega} r>w_{i} a$, consistent with a participation constraint that is not binding.

With this combination of $r$ and $\omega_{f}$, expected formal employer profit, when only the minimum wage constraint binds, is

$$
\begin{aligned}
& \max _{\omega_{f}, r} a-\omega_{f}-\tau_{\pi}(a-r)-\bar{\phi} \bar{p}\left(r-\omega_{f}\right)^{2}, \text { s.t. } r=\bar{w} \\
= & \max _{\omega_{f}}\left(1-\tau_{\pi}\right) a+\tau_{\pi} \bar{w}-\left[\omega_{f}+\bar{\phi} \bar{p}\left(\bar{w}-\omega_{f}\right)^{2}\right]
\end{aligned}
$$

The solution to the employer's decision problem when only the minimum wage constraint is binding is thus: ${ }^{12}$

$$
r^{*}(a)=\bar{w}, \quad \omega_{f}^{*}(a)=\bar{w}-\frac{1}{2 \bar{\phi} \bar{p}}, \quad \omega_{f}^{*}(a)-r^{*}(a) \tau_{\omega}=\bar{w}\left(1-\tau_{\omega}\right)-\frac{1}{2 \bar{\phi} \bar{p}} .
$$

As shown in (19), formal employers in this regime reports the minimum mandated wage $\bar{w}$ as the wage cost per worker. The actual pre-tax take home wage $\omega_{f}^{*}(a)$ is strictly less than the reported wage $\omega_{f}^{*}(a)=\bar{w}-1 /(2 \bar{\phi} \bar{p})<\bar{w}$. The associated tax evasion, is

$$
r^{*}(a)-\omega_{f}^{*}(a)=\frac{1}{2 \bar{\phi} \bar{p}} .
$$

Clearly, the higher the frequency of tax auditing $\bar{\phi}$ and the more severe the penalty $\bar{p}$, the smaller will be the extent of tax evasion. Interestingly, while workers are paid strictly less than the minimum wage, their take home sub-minimum wage co-moves with the mandated minimum dollar-for-dollar. Consequently, equilibrium tax evasion, or equivalently the difference between $r^{*}(a)$ and $\omega_{f}^{*}(a)$, is strictly invariant to $\bar{w}$. Furthermore, since small changes in the two tax rates $\left(\tau_{\pi}\right.$, and $\left.\tau_{\omega}\right)$ bear no

\footnotetext{
${ }^{12}$ The associated equilibrium likelihood of tax audit $\phi^{*}(a)=\bar{\phi}\left|r^{*}(a)-\omega_{f}^{*}(a)\right|=1 /(2 \bar{p})$ continues to lie in the interior of the $[0,1]$ interval for $\bar{p} \geq 1$.
} 
impact on the severity / frequency of the penalty associated with wage under-reporting, these changes have no impact on the extent of tax evasion either.

Turning now to minimum wage non-compliance, the difference between the mandated post tax wage and the actual post tax wage is:

$$
\bar{w}\left(1-\tau_{\omega}\right)-\left(\omega_{f}^{*}(a)-r^{*}(a) \tau_{\omega}\right)=\frac{1}{2 \bar{\phi} \bar{p}}>0 .
$$

Thus, minimum wage non-compliance is synonymous with tax evasion, in that both are exactly equal to $1 /(2 \bar{\phi} \bar{p})>0$. This implies that employers in this regime do not comply with the minimum wage legislation, and the post-tax income of formal workers is less than what the minimum wage mandate would require. Perhaps more importantly, since the extent of wage over-reporting depends on the strength of tax enforcement $\bar{\phi} \bar{p}$ alone, the extent of minimum wage non-compliance is independent of the size of the minimum wage, but strictly decreasing in $\bar{\phi} \bar{p}$.

Substituting (19) into (9), and using (6), the incidence of informality $1-\alpha^{*}(a)$ is:

$$
1-\theta^{1 /(1-\beta)}\left(\left[\left(1-\tau_{\pi}\right)(a-\bar{w})+1 /(4 \bar{\phi} \bar{p})\right] / c_{f}\right)^{\beta /(1-\beta)} .
$$

Any policy measure that decreases formal employer profits will increase the incidence of informality. Routine differentiation reveals that these policies include increases in the minimum wage, increases in the profit tax rate $\tau_{\omega}$, and a strengthening of the tax enforcement regime $\bar{\phi} \bar{p}$. Note in particular that since the participation constraint is not binding here, small changes in the personal income tax $\tau_{\omega}$ does not impact formal employers' ability to attract workers at constant $\omega_{f}^{*}(a)$, and the incidence of informality is thus in fact independent of $\tau_{\omega}$.

Let us now verify the starting premises in this regime: (i) the minimum wage constraint is the only binding constraint, and (ii) reported pre-tax profit $a-r^{*}(a)$ is strictly positive. From (19), the minimum wage constraint is the only binding constraint if and only if $\omega_{f}^{*}(a)-r^{*}(a) \tau_{\omega}>w_{i} a$, or if the minimum wage is sufficiently high relative to the productivity of the workers:

$$
\bar{w}>\frac{w_{i} a+1 /(2 \bar{\phi} \bar{p})}{1-\tau_{\omega}} .
$$

From (19), reported pre-tax profit is in fact always strictly positive in this regime upon substituting (19) into (14),

$$
\pi_{f}^{*}(a)=\left(1-\tau_{\pi}\right)(a-\bar{w})+1 /(4 \bar{\phi} \bar{p})>0,
$$

whenever worker productivity exceeds the minimum wage. This automatically rules out Regime $\mathrm{V}$ discussed at the beginning of this section, where the minimum wage is the only binding constraint in the presence of non-positive reported profit. 
Figure 1b illustrates. As before in Figure 1a, to the right of the 45 degree line are all combinations of $a$ and $\bar{w}$ such that worker productivity exceeds the minimum wage. The upward sloping schedule labeled MW divides all $(a, \bar{w})$ combinations into two groups. For minimum wage sufficiently high and above the MW schedule, the inequality in (20) is satisfied and hence the minimum wage constraint is the only binding constraint. Otherwise, for relatively low minimum wage and below the MW schedule, the inequality in (20) is violated and the participation constraint begins to bind. Using (21), all employer worker matches $(a, \bar{w})$ that lie above the MW schedule report positive profits.

Summarizing, in sharp contrast to the earlier regime where the participation constraint is the only binding constraint when the minimum wage is low relative to the productivity of workers, the minimum wage constraint is the only binding constraint when the minimum wage is sufficiently high relative to the productivity of workers $\bar{w}>\left(w_{i} a+1 /(2 \bar{\phi} \bar{p})\right) /\left(1-\tau_{\omega}\right)$ (from $\left.(20)\right)$. Also unlike the previous regime where tax evasion depends critically on the tax policy induced tax gap $\tau_{\pi}-\tau_{\omega}$, while minimum wage non-compliance depends on the minimum wage policy mandated wage hike $\bar{w}\left(1-\tau_{\omega}\right)-w_{i} a$, minimum wage non-compliance is in fact synonymous with tax evasion here in that they are both given by the same expression that depends only on the strength of the tax enforcement in place $1 /(2 \bar{\phi} \bar{p})$ (from (19)).

Thus, the stricter the tax enforcement regime, the higher will be the actual wage that formal employers voluntarily pay, and tax enforcement becomes a means to discourage tax evasion, as well as a means to encourage minimum wage compliance. Indeed, for all employer-worker matches in this regime where the participation constraint is not binding, the formal sector wage accounting appropriately for the tax on wage income, $\bar{w} \tau_{\omega}$, or $\bar{w}\left(1-\tau_{\omega}\right)-1 /(2 \bar{\phi} \bar{p})$, strictly exceeds the reservation wage $w_{i} a$. Since the formal take home wage $\omega_{f}^{*}(a)$ improves with tax enforcement $\bar{\phi} \bar{p}$, the formalinformal pay gap

$$
\omega_{f}^{*}(a)-r^{*}(a) \tau_{\omega}-w_{i} a=\bar{w}\left(1-\tau_{\omega}\right)-\frac{1}{2 \bar{\phi} \bar{p}}-w_{i} a
$$

is thus strictly increasing in the strength of tax enforcement as well. This is an important observation, to be developed further in the section to follows: even in the complete absence of minimum wage enforcement, both the reported and the actual post tax take home wage of formal sector worker strictly increases with a sufficiently high minimum wage satisfying (20). The hike in take home wages from the reservation level $w_{i} a$ in $(5)$ to $\bar{w}\left(1-\tau_{\omega}\right)-1 /(2 \bar{\phi} \bar{p})$ in (19) is subject to the implicit discipline

of the system of tax enforcement and audit in place $\bar{\phi} \bar{p}$. The stricter the enforcement against tax evasion, the steeper will be the hike in workers' take home wage relative to the reservation level.

\section{Binding Participation and Minimum Wage Constraint}

Unlike in regimes I and II where the minimum wage is respectively sufficiently low, and sufficiently 
high, for minimum wage in the intermediate range, $\bar{w} \in\left(\left(w_{i} a+\delta\right) /\left(1-\tau_{\omega}\right),\left(w_{i} a+1 /(2 \bar{\phi} \bar{p})\right) /\left(1-\tau_{\omega}\right)\right)$, both the participation and the minimum wage constraints are binding. The two binding constraints jointly and uniquely determine the reported and take home wages in this regime: ${ }^{13}$

$$
r^{*}(a)=\bar{w}, \quad \omega_{f}^{*}(a)=w_{i} a+\bar{w} \tau_{\omega}, \quad \omega_{f}^{*}(a)-r^{*}(a) \tau_{\omega}=w_{i} a .
$$

With a binding participation constraint, formal workers receive an after-tax pay that is equal to their reservation wage $w_{i} a$. With a binding minimum wage constraint, employers report a wage cost that is equal to the minimum wage. Jointly, these imply that formal employers compensate workers simply by paying the reservation wage $w_{i} a$, and top off with an additional amount that compensates workers for the personal income tax that a formal sector worker owes tax authorities $\bar{w} \tau_{\omega}$, evaluated at the reported wage cost $\bar{w}$.

The associated equilibrium tax evasion in this regime is

$$
r^{*}(a)-\omega_{f}^{*}=\bar{w}\left(1-\tau_{\omega}\right)-w_{i} a>0
$$

where the inequality follows since $\bar{w} \in\left(\left(w_{i} a+\delta\right) /\left(1-\tau_{\omega}\right),\left(w_{i} a+1 /(2 \bar{\phi} \bar{p})\right) /\left(1-\tau_{\omega}\right)\right)$. Thus, employers in this regime also over-report wage costs. In addition, with both constraints binding, equilibrium tax evasion is simply given by the minimum wage policy mandated wage hike $\bar{w}\left(1-\tau_{\omega}\right)-w_{i} a$. Importantly, tax evasion is now fully independent of the frequency of tax audit $\bar{\phi}$ or the penalty $\bar{p}$. Small changes in the profit tax $\tau_{\pi}$ has surprisingly no local impact on tax evasion either. Effectively, in this range, the minimum wage is high enough so that reporting any wage higher than $\bar{w}$ invites too high an increase in expected penalty. Meanwhile, worker productivity is also high enough in this range, so that simply paying workers a wage that minimizes wage plus expected penalty costs, as in regime II above, is not sufficient to guarantee participation. Consequently, equilibrium tax evasion reflects these considerations as employers report exactly the minimum wage, while setting the true wage cost at a level that makes a formal job no worse than an informal job.

In terms of minimum wage non-compliance, we note that minimum wage non-compliance is once again synonymous with tax evasion:

$$
\bar{w}\left(1-\tau_{\omega}\right)-\left[\omega_{f}^{*}(a)-r^{*}(a) \tau_{\omega}\right]=\bar{w}\left(1-\tau_{\omega}\right)-w_{i} a>0
$$

though the extent of minimum wage non-compliance is now independent of the strength of tax enforcement, unlike regime II. Taken together, both equilibrium tax evasion and equilibrium minimum non-compliance strictly increases with the mandated post-tax income $\bar{w}\left(1-\tau_{\omega}\right)$. However, minimum

\footnotetext{
${ }^{13}$ The associated equilibrium likelihood of tax audit $\phi^{*}(a)=\bar{\phi}\left|r^{*}(a)-\omega_{f}^{*}(a)\right|=\bar{\phi}\left[\bar{w}\left(1-\tau_{\omega}\right)-w_{i} a\right] \in\left(\left(\tau_{\pi}-\tau_{\omega}\right) /(2 \bar{p}(1-\right.$ $\left.\left.\left.\tau_{\omega}\right)\right), 1 /(2 \bar{p})\right)$ lies in the interior of the $[0,1]$ interval for $\bar{w} \in\left(\left(w_{i} a+\delta\right) /\left(1-\tau_{\omega}\right),\left(w_{i} a+1 /(2 \bar{\phi} \bar{p})\right) /\left(1-\tau_{\omega}\right)\right)$ in this regime, and $\bar{p} \geq 1$.
} 
wage non-compliance can be expected to decrease with work productivity $a$, and thus the reservation wage $w_{i} a$.

Now, the incidence of informality $1-\alpha^{*}(a)$ is:

$$
1-\theta^{1 /(1-\beta)}\left(\pi_{f}^{*}(a) / c_{f}\right)^{\beta /(1-\beta)}
$$

where

$$
\pi_{f}^{*}(a)=\left(1-\tau_{\pi}\right)(a-\bar{w})+\frac{1}{4 \bar{\phi} \bar{p}}-\bar{\phi} \bar{p}\left(\frac{1}{2 \bar{\phi} \bar{p}}-\left[\bar{w}\left(1-\tau_{\omega}\right)-w_{i} a\right]\right)^{2}>0 .
$$

It is straightforward to verify that $\pi_{f}^{*}(a)$ is strictly decreasing in all three policies $\tau_{\pi}, \tau_{\omega}$ and $\bar{w}$ in this range. Consequently, the incidence of informality is accordingly strictly increasing whenever either one of the two tax rates, or when the minimum wage rises.

To close this section, let us check that reported pre-tax profit $a-r^{*}(a)$ is strictly positive in this regime as well. From $(23)$ above, $\pi_{f}^{*}(a)$ is always strictly positive. This automatically rules out Regime VI, where both constraints are binding in the presence of non-positive reported profit.

Figure 1c illustrates the $(a, \bar{w})$ combinations that come under this regime. As shown, all $(a, \bar{w})$ combinations to the right of the 45 degree line, and in between the PC and MW schedules belong this regime.

To summarize, for intermediate levels of the minimum wage, both the participation constraint and the minimum wage constraint are binding. While employers continue to under-report wage cost from (22), the reported wage cost is bounded below by $\bar{w}$ here, and workers' post tax take home wage is bounded below by the reservation wage. Consequently, tax evasion and minimum wage noncompliance are once again synonymous, though this value is now equal to the extent to which the government mandated post tax wage $\bar{w}\left(1-\tau_{\omega}\right)$ exceeds workers' reservation wage $w_{i} a$. In sharp contrast to regime II, where employers also report the minimum wage as the wage cost, the strength of tax policy enforcement no longer play a role in determining employers' compliance to tax and minimum wage laws (from (22)). Similarly, the profit tax rate has no impact on equilibrium tax evasion or minimum wage non-compliance (also from (22)).

\subsection{Zero Reported Profits}

Since regimes V and VI have both been ruled out in the preceding paragraphs, a final regime to consider here involves regime IV. This has been shown to be a real possibility in equilibrium for the case where the participation constraint is the only binding constraint, and specifically when worker productivity is lower than a threshold:

$$
a<\frac{\delta}{1-\tau_{\omega}-w_{i}}
$$


as shown in (18).

\section{Binding Participation Constraint}

When reported profit is non-positive $r \geq a$, and when the participation constraint is the only binding constraint, formal employers' decision problem is as follows:

$$
\begin{aligned}
& \max _{\omega_{f}, r} a-\omega_{f}-\bar{\phi} \bar{p}\left(r-\omega_{f}\right)^{2}, \text { s.t. } r \geq a, \omega_{f}-r \tau_{\omega}=w_{i} a \\
= & \max _{r} a-w_{i} a-r \tau_{\omega}-\bar{\phi} \bar{p}\left(r\left(1-\tau_{\omega}\right)-w_{i} a\right)^{2}, \quad \text { s.t. } r \geq a .
\end{aligned}
$$

As shown, expected profit is strictly decreasing in $r$. Intuitively, since formal employers are no longer subject to profit tax upon reporting non-positive profit, further raising the reported wage cost $r$ will only raise the expected penalty associated with the mis-reporting of profit $\bar{\phi} \bar{p}\left(r\left(1-\tau_{\omega}\right)-w_{i} a\right)^{2}$, with otherwise no further beneficial impact on profits. The solutions to the employer's problem in this case involves setting ${ }^{14}$

$$
r^{*}(a)=a, \omega_{f}^{*}(a)=a\left(w_{i}+\tau_{\omega}\right), \omega_{f}^{*}(a)-r^{*}(a) \tau_{\omega}=w_{i} a,
$$

The associated tax evasion is given simply by

$$
r^{*}(a)-\omega_{f}^{*}(a)=a\left(1-\tau_{\omega}-w_{i}\right)
$$

Since formal employers report zero profits $r^{*}(a)=a$, and make job offers by compensating workers for the reservation wage $w_{i} a$ and any applicable personal income tax $\tau_{\omega} r^{*}(a)=\tau_{\omega} a$, the extent of tax evasion is independent of the strength of tax enforcement, or the size of the minimum wage.

Meanwhile, the extent of minimum wage non-compliance is given by:

$$
\bar{w}\left(1-\tau_{\omega}\right)-\left(\omega_{f}^{*}-r^{*}(a) \tau_{\omega}\right)=\bar{w}\left(1-\tau_{\omega}\right)-w_{i} a
$$

Based on reasoning that should by now be familiar, since the participation constraint is binding, employers make job offers that are just attractive enough to compensate workers for their forgone reservation earning $w_{i} a$. It follows that the extent of minimum wage non-compliance is given by the government mandated post tax take-home wage $\bar{w}\left(1-\tau_{\omega}\right)$ and the reservation wage itself. Thus, the strength of tax enforcement does not have any local impacts on minimum wage non-compliance.

Finally, the incidence of informality $1-\alpha^{*}(a)$ is given by:

$$
1-\theta^{1 /(1-\beta)}\left(\pi_{f}^{*}(a) / c_{f}\right)^{\beta /(1-\beta)}
$$

\footnotetext{
${ }^{14}$ The associated equilibrium likelihood of tax audit $\phi^{*}(a)=\bar{\phi}\left|r^{*}(a)-\omega_{f}^{*}(a)\right|=\bar{\phi} a\left(1-\tau_{\underline{\omega}}-w_{i}\right) \in\left(\left(\tau_{\pi}-\tau_{\omega}\right) /(2 \bar{p}(1-\right.$ $\left.\left.\left.\tau_{\omega}\right)\right), 1 /(2 \bar{p})\right)$ lies in the interior of the $[0,1]$ interval for $\bar{w} \in\left(\left(w_{i} a+\delta\right) /\left(1-\tau_{\omega}\right),\left(w_{i} a+1 /(2 \bar{\phi} \bar{p})\right) /\left(1-\tau_{\omega}\right)\right)$ in this regime, and $\bar{p} \geq 1$.
} 
where

$$
\pi_{f}^{*}(a)=\frac{1}{4 \bar{p} \bar{\phi}}-\bar{p} \bar{\phi}\left(\frac{1}{2 \bar{p} \bar{\phi}}-a\left(1-\tau_{\omega}-w_{i}\right)\right)^{2},
$$

At zero reported profit, actual profit $\pi_{f}^{*}(a)$, and thus the incidence of informality, $1-\alpha^{*}(a)$, are both independent of the profit tax $\tau_{\pi}$. However, increases in the personal income tax raises actual wage $\operatorname{cost} \omega_{f}^{*}$, and decreases formal sector profits. Thus, the incidence of informality is strictly increasing in the personal income tax rate. Strengthening tax enforcement similarly lowers formal sector profit, and increases the incidence of informality.

Synthesizing our findings up to this point, Tables 4 and 5 display the tax evasion and minimumwage non-compliance responses to the four policy measures $\tau_{\pi}, \tau_{\omega}, \bar{w}$, and $\bar{\phi} \bar{p}$. A number of features are particularly striking. First, with the lone exception of the case where the personal income tax on minimum wage workers is greater than the profit tax rate, which we have demonstrated in Table 3 to be the exception rather than the rule empirically, we find that employers over-report wage costs. From the perspective of tax authorities, this over-reporting of wages manifests itself as tax evasion. From the perspective of labor inspectors, this over-reporting of wages gives rise to minimum wage non-compliance. However, tax evasion and minimum wage non-compliance made possible by less than perfect enforcement raises expected formal employer profits. This puts checks on the incidence of informality, in which employers pay no taxes at all, and the minimum wage legislation is neither respect nor enforced.

Second, in both regimes II and III where the minimum wage is sufficiently high, or at an intermediate range, we find that tax evasion and minimum wage non-compliance are synonymous. Thus while the four policies have regime-specific impacts depending on which of two constraints are binding and whether reported profit is positive, the effects of four policies on tax evasion, and on minimum wage non-compliance are identical. In other words, there are well-defined regimes of interest in which policies targeted towards mitigating tax evasion and minimum wage compliance can be complementary to each other.

Third, it is clear from Tables 4 and 5 that a minimum wage hike can encourage tax evasion (regime III), while raising the personal income tax can tame minimum wage non-compliance (regimes I, III and IV). Similarly, strengthening tax enforcement can discourage tax evasion (regimes I and II) and mitigate against minimum wage non-compliance (regime II). Thus, there are indeed crosscutting impacts that a minimum wage policy can have on tax evasion, and that tax policies can have on minimum wage compliance.

This apparent plethora of possible comparative statics responses suggests that the devil is in the details, and furthermore, that the nuanced responsiveness of tax evasion and minimum wage noncompliance to policy changes is likely to depend on the precise specification of the penalty scheme, 
the tax auditing technology, in addition to the height of the minimum wage, the two taxes, as well as the strength of the tax enforcement regime. All of this make for a very fruitful agenda for future research, and particularly on the design of an optimal penalty scheme. This said, our analysis so far summarized in Tables 4 and 5 suggest a number of generalizations, and testable hypotheses:

Proposition 1 For all $a \geq \delta /\left(1-\tau_{\omega}-w_{i}\right)$, and minimum wage $\bar{w}<a$, the extent of tax evasion $r^{*}-\omega_{f}^{*}$ is

- weakly increasing in the profit tax rate $\tau_{\pi}$;

- weakly decreasing in the personal income tax rate $\tau_{\omega}$;

- weakly increasing in the minimum wage $\bar{w}$, and

- weakly decreasing in the strength of tax enforcement $\bar{\phi} \bar{p}$.

The extent of minimum wage non-compliance is

- independent of the profit tax rate $\tau_{\pi}$;

- weakly decreasing in the personal income tax rate $\tau_{\omega}$;

- weakly increasing in the minimum wage $\bar{w}$, and

- weakly decreasing in the strength of tax enforcement $\bar{\phi} \bar{p}$.

Table 6 summarizes responsiveness of the incidence of informality with respect to the four policy measures. Contrary to Proposition 1, the effectiveness of the four policies are more uniform: Proposition 2 For all minimum wage $\bar{w}<a$, the incidence of informality is weakly increasing in the profit tax rate $\tau_{\pi}, \tau_{\omega}$, and the minimum wage $\bar{w}$, and strictly increasing in the strength of tax enforcement $\bar{\phi} \bar{p}$.

These results embody important policy implications, and some of these may not be apparent at first sight. Consider, for example, the consequences of a flat tax reform, which equates $\tau_{\omega}$ and $\tau_{\pi} \cdot{ }^{15}$ Starting from an equilibrium with $\tau_{\omega}<\tau_{\pi}$, a flat tax reform can be accomplished either by raising $\tau_{\omega}$, or by decreasing $\tau_{\pi}$. While our analysis of regime I suggest that closing the gap $\tau_{\pi}-\tau_{\omega}$ decreases individual formal sector employer's incentives to evade taxes, Proposition 2 suggests that the overall tax consequences of a flat tax reform, accounting for the incidence of informality, will likely depend critically on whether the proposed flat tax requires an increase in $\tau_{\omega}$ - which is expected to entice employers to turn to the informal sector, or a reduction in $\tau_{\pi}$ - which will have the exact opposite impact.

\footnotetext{
${ }^{15}$ We follow convention and refer a flat tax reform to a policy of constant marginal tax rate.
} 


\section{Optimal Policies for Poverty Alleviation}

A key departure of this model from the existing literature is in its unique ability to identify and distinguish between two wage distributions that prevail among workers of differing skills. First, the reported wage distribution pertains to the wage distribution that can be ascertained from firm level tax records for example. Second, the actual wage distribution pertains to the true take home income of working individuals that may be ascertained from household / labor force surveys for example.

Our objective in this section is to evaluate the effectiveness of policies in alleviating poverty, evaluated based on the actual, rather than the reported post tax take home wage of individual workers. To do so, we first combine Figures 1a - 1c to yield Figure 2, which summarizes in one diagram the juxtaposition of the four regimes (I - IV) examined so far. To recall,

- in regime I, the reported wage exceeds the minimum wage, formal worker are paid their reservation income post tax, and employers report positive profits;

- in regime II, the reported wage is equal to the minimum wage, formal workers are paid strictly higher than their reservation income post tax, and employers report positive profits;

- in regime III, the reported wage is equal to the minimum wage, formal workers are paid their reservation income post tax, and employers report positive profits;

- in regime IV, the reported wage exceeds the minimum wage, formal workers are paid their reservation income post tax, and employers report zero profit.

We begin with a preliminary result, which can be verified simply by inspection of Figure 2:

Proposition 3 I. For all $a>\bar{w}$ and tax enforcement sufficiently strict ( $\bar{\phi} \bar{p}$ sufficiently large) such that

$$
a>\frac{1}{2 \bar{\phi} \bar{p}\left(1-\tau_{\omega}-w_{i}\right)},
$$

the post-tax take home earnings of formal sector workers strictly exceed their reservation benchmark $w_{i}$ a if and only if the minimum wage exceeds the threshold:

$$
\bar{w} \geq \frac{w_{i} a+1 /(2 \bar{\phi} \bar{p})}{1-\tau_{\omega}-w_{i}} .
$$

The stricter the tax enforcement regime, and thus the higher $\bar{\phi} \bar{p}$ is, the lower this threshold will be. II. For all $a>\bar{w}$ and tax enforcement sufficiently lax, however, with

$$
a<\frac{1}{\left(2 \bar{\phi} \bar{p}\left(1-\tau_{\omega}-w_{i}\right)\right.}
$$


there does not exist a minimum wage $\bar{w}<$ a that can raise the actual post-tax income of formal sector workers beyond the reservation benchmark $w_{i} a$.

When tax enforcement is strict enough, the threshold minimum wage is given simply by the MW schedule in Figure 2, which separates $(a, \bar{w})$ in regime II from that of I, III and IV. As noted earlier in our discussion of the employer's decision problem in regime II, what is particularly notable here is that a minimum wage is shown to raise the income of formal sector workers even though an official minimum wage enforcement mechanism is non-existent. Rather, enforcement against tax evasion serves as the implicit discipline device, and prevents formal employers from over-stating their wage cost by too much, or equivalently, enforcement against tax evasion effectively discourages formal employers from paying workers too low a wage relative to the reported minimum wage $\bar{w}$.

Now, the vertical dotted line at $\frac{1}{2 \bar{\phi} \bar{p}\left(1-\tau_{\omega}-w_{i}\right)}$ in Figure 2 divides the range of possible workers' skill levels into two regions separated by a critical skill level $\bar{a}=\frac{1}{2 \bar{\phi} \bar{p}\left(1-\tau_{\omega}-w_{i}\right)}$. To the right of $\bar{a}$ and hence for workers with relatively high skills given the tax enforcement regime, a minimum wage which raises the post-tax take home earnings of formal sector workers beyond $w_{i} a$ can always be found for region II is non-empty for $a \geq \frac{1}{2 \bar{\phi} \bar{p}\left(1-\tau_{\omega}-w_{i}\right)}$. However, to the left of $\bar{a}$ and hence for workers with sufficiently low skills given the tax enforcement regime, there does not exist a minimum wage, however high or low, that raises the post tax take home income of formal sector workers beyond the reservation level, since the set of $(a, \bar{w})$ in region II with $a<\bar{a}$ is empty. Strengthening tax enforcement through an increase in $\bar{\phi} \bar{p}$ shifts this critical skill level $\bar{a}$ to the left, accommodating more formal workers whose income can be raised beyond $w_{i} a$ via an appropriately set minimum wage.

In what follows, we examine the choice of a minimum wage and tax policy package $\left\{\bar{w}, \tau_{\pi}, \tau_{\omega}\right\}$ for each skill level that minimizes poverty among workers of a given skill level $a$, taking as given the strength of the tax enforcement measures $\bar{\phi} \bar{p}$ in place. To this end, let $z>0$ denote the poverty line. Consider all skill levels such that the benchmark reservation income is less than the poverty line $w_{i} a<z$, or

$$
a>z / w_{i} \equiv a_{z}
$$

In the absence of poverty intervention through a minimum wage for example, all workers with $a<a_{z}$ are poor, while those with $a \geq a_{z}$ are not. We consider the policy problem:

$$
\min _{\bar{w}, \tau_{\pi}, \tau_{\omega}} 1-\alpha^{*}(a), \text { s.t. } \omega_{f}^{*}(a)-r^{*}(a) \tau_{\omega} \geq z
$$

for $a<a_{z}$. The objective of the policy maker is thus to minimize the incidence of informality, while at the same time guaranteeing formal sector workers an income level no less than the poverty line. Since $a<a_{z}$, all informal workers are by definition poor. Stated differently, the objective of the 
policy maker is to minimize the poverty head count, when formal sector workers are guaranteed an income level no less than the poverty line.

From Proposition 3, we know that in order to strictly raise the income of formal sector workers above the reservation level $w_{i} a$, what is required is a minimum wage that is sufficiently high, as well as a tax enforcement mechanism in place that is sufficiently strict, so that regime II applies. There are thus two distinctive possibilities:

1. if tax enforcement is sufficiently lax such that

$$
a_{z} \leq \frac{1}{2 \bar{\phi} \bar{p}\left(1-\tau_{\omega}-w_{i}\right)},
$$

it follows from Proposition 3 that there does not exist a minimum wage $\bar{w}<a$ that can lift any worker with $a<a_{z}$ out of poverty since regime II is empty;

2. if tax enforcement is strict enough so that

$$
a_{z}>\frac{1}{2 \bar{\phi} \bar{p}\left(1-\tau_{\omega}-w_{i}\right)},
$$

there are thus two types of workers who will live under the poverty line in the absence of policy intervention. Those with relatively low skills $a<\frac{1}{2 \bar{\phi} \bar{p}\left(1-\tau_{\omega}-w_{i}\right)}$ for whom regime II is empty, and those with relatively high skills $a \in\left[\frac{1}{2 \bar{\phi} \bar{p}\left(1-\tau_{\omega}-w_{i}\right)}, a_{z}\right]$, for whom regime II is non-empty. For the former group of lower skill workers, a minimum wage that lifts workers out of poverty continues to be non-existent.

Suppose therefore that $a_{z}>\frac{1}{2 \bar{\phi} \bar{p}\left(1-\tau_{\omega}-w_{i}\right)}$. Let us consider the group of workers with relatively high skills, $a>\left[\frac{1}{2 \bar{\phi} \bar{p}\left(1-\tau_{\omega}-w_{i}\right)}, a_{z}\right]$, who would otherwise be living under the poverty line in the absence of policy intervention. From Proposition 3, any minimum wage $\bar{w}<a$ but greater than the threshold demarcated by the MW schedule in Figure 2, $\frac{w_{i} a+1 /(2 \bar{\phi} \bar{p})}{1-\tau_{\omega}-w_{i}}$, raises the post-tax take home income of formal sector workers beyond $w_{i} a$. From (19), the corresponding post tax take home wage is given by the government mandated post-tax take home wage $\bar{w}\left(1-\tau_{\omega}\right)$, net of the extent of wage underreporting, $1 /(2 \bar{\phi} \bar{p})$ in this regime, or $\omega_{f}^{*}(a)-r^{*}(a) \tau_{\omega}=\bar{w}\left(1-\tau_{\omega}\right)-1 /(2 \bar{p} \bar{\phi})$. The higher the minimum wage, the higher will be the take home wage of formal sector workers in this regime. It follows that if the post-tax take home wage is to exceed the poverty line, the minimum wage will need to be sufficiently high, since

$$
\omega_{f}^{*}(a)-r^{*}(a) \tau_{\omega} \geq z \quad \Leftrightarrow \quad \bar{w} \geq \frac{z+1 /(2 \bar{\phi} \bar{p})}{1-\tau_{\omega}} \equiv \bar{w}(z) .
$$

(26) above shows that the smallest minimum wage $\bar{w}(z)$ that lifts formal sector workers out of poverty is decreasing in the strength of the tax enforcement regime, and increasing in the personal income 
tax. Such a wage is feasible, in the sense that it does not exceed the net output $a$ of a worker if and only if

$$
\bar{w}(z)=\frac{z+1 /(2 \bar{\phi} \bar{p})}{1-\tau_{\omega}}<a .
$$

It follows that for all workers in the range $a<\bar{w}(z)$, a minimum wage $\bar{w}<a$ that lifts workers out of poverty does not exist. Otherwise, for workers in the range $a \in\left[\bar{w}(z), a_{z}\right]$, setting $\bar{w}=\bar{w}(z)$ puts formal sector workers exactly at the poverty line.

Now, turning to the minimization of poverty head count, which requires minimizing the incidence of informality subject to (26) above, recall from (6) and (21) that the incidence of informality in regime II is given by:

$$
1-\theta^{1 /(1-\beta)}\left(\left[\left(1-\tau_{\pi}\right)(a-\bar{w})+1 /(4 \bar{\phi} \bar{p})\right] / c_{f}\right)^{\beta /(1-\beta)} .
$$

Clearly, the higher the minimum wage, the higher will be the incidence of informality implying that the constraint in (25) must be strictly binding. Substituting $\bar{w}(z)$ into the equation above, it is straightforward to see that the incidence of informality is furthermore strictly increasing in $\tau_{\pi}$ as well as $\tau_{\omega}$. We have thus:

Proposition 4 I. If tax enforcement is sufficiently lax, so that $a_{z} \leq 1 /\left(2 \bar{\phi} \bar{p}\left(1-\tau_{\omega}-w_{i}\right)\right)$, there does not exist a poverty alleviating minimum wage for all $a<a_{z}$.

II. If tax enforcement is sufficiently strict, so that $a_{z}>1 /\left(2 \bar{\phi} \bar{p}\left(1-\tau_{\omega}-w_{i}\right)\right)$, a poverty alleviating minimum wage does not exist for low skilled workers with $a<\bar{w}(z) \equiv \frac{z+1 /(2 \bar{\phi} \bar{p})}{1-\tau_{\omega}}$. For higher skilled workers, with $a \in\left[\bar{w}(z), a_{z}\right]$, setting

$$
\bar{w}=z+\frac{1}{2 \bar{p} \bar{\phi}}, \quad \tau_{\pi}=0, \quad \tau_{\omega}=0
$$

minimizes the poverty head count.

To verify the final item noted in Proposition 4, suppose that the minimum wage is set below $z+\frac{1}{2 \bar{p} \phi}$ as indicated in the proposition. It follows from (26) that formal sector workers live below the poverty line. Since all informal sector workers live below the poverty line as well for $a<a_{z}$, a minimum wage policy $\bar{w}$ that stipulates $\bar{w}<z+\frac{1}{2 \bar{p} \phi}$ is completely ineffective in alleviating poverty.

Now suppose instead that the minimum wage is set above or equal to $z+\frac{1}{2 \bar{p} \phi}$. It follows from (26) that all formal sector workers live at or above the poverty line, but all informal sector workers remain poor. To minimize the incidence of poverty, the policy maker should set $\bar{w}$ exactly at $\bar{w}(z)$ and $\tau_{\pi}=\tau_{\omega}=0$, since the incidence of informality decreases with $\bar{w}, \tau_{\pi}$ and $\tau_{\omega}$.

Importantly, Proposition 3 demonstrates that a poverty minimizing minimum wage is set at the poverty line $z$, plus an additional expression that depends only on the strength of tax enforcement 
$\bar{\phi} \bar{p}$. This remarkably simple formula is independent of the productivity of the worker, or the informal sector wage. What Proposition 3 also points out is that this such an optimal minimum wage can be effective even when the minimum wage itself is not enforced, but that a sufficiently strict tax enforcement regime is in place.

\section{Optimal Policies for Tax Compliance}

We focus now on evaluating the policy package $\left\{\bar{w}, \tau_{\pi}, \tau_{\omega}\right\}$ that maximizes total expected government revenue, including all tax revenue on profits and wage earnings, as well as any applicable fines and penalties collected, taking once again as given the strength of the tax enforcement regime in place.

Since informal employers and workers do not pay taxes, total government tax revenue $G(a)$ is given simply by the sum of per employer tax on formal profits $\tau_{\pi} \min \left\{0, a-r^{*}(a)\right\}$, tax on wage earnings $\tau_{\omega} r^{*}(a)$, and the expected fines and penalties collected: $\bar{\phi} \bar{p}\left(r^{*}(a)-\omega_{f}^{*}(a)\right)^{2}$, multiplied by the total number of formal sector employers, $\alpha^{*}(a) N(a)$. From (14), and by definition of $\pi_{f}^{*}(a)$,

$$
\begin{aligned}
G(a) & =N(a) \theta^{1 /(1-\beta)}\left(\frac{\pi_{f}^{*}(a)}{c_{f}}\right)^{\beta /(1-\beta)}\left(\tau_{\pi} \min \left\{0, a-r^{*}(a)\right\}+\tau_{\omega} r^{*}(a)+\bar{\phi} \bar{p}\left(r^{*}(a)-\omega_{f}^{*}(a)\right)^{2}\right) \\
& =N(a) \theta^{1 /(1-\beta)}\left(\frac{\pi_{f}^{*}(a)}{c_{f}}\right)^{\beta /(1-\beta)}\left(a-\omega_{f}^{*}(a)+\tau_{\omega} r^{*}(a)-\pi_{f}^{*}(a)\right)
\end{aligned}
$$

Intuitively, the true pre-tax profit $\left(a-\omega_{f}^{*}(a)+\tau_{\omega} r^{*}(a)\right)$ net of the post-tax post-penalty profit per employer $\pi_{f}^{*}(a)$ gives the total tax take per employer.

Using the results in section 3.1, government revenue can be evaluated at $(a, \bar{w})$ combinations consistent with regimes I - IV. Suppose to begin with that the minimum wage is sufficiently high, as in regime II, so that the participation constraint is not binding. From (19), the post-tax take home wage of a formally employed worker is $\omega_{f}^{*}(a)-\tau_{\omega} r^{*}(a)=\bar{w}\left(1-\tau_{\omega}\right)-1 /(2 \bar{p} \bar{\phi})$, while formal sector expected profit $\pi_{f}^{*}(a)$ as displayed in (21), has been shown to be strictly decreasing in the minimum wage $\bar{w}$. Substituting these expressions into (27) above, we obtain:

$$
G(a)=N(a) \theta^{1 /(1-\beta)}\left(\frac{\pi_{f}^{*}(a)}{c_{f}}\right)^{\beta /(1-\beta)}\left(a \tau_{\pi}-\bar{w}\left(\tau_{\pi}-\tau_{\omega}\right)+\frac{1}{4 \bar{p} \bar{\phi}}\right)
$$

It follows by inspection that since $\tau_{\pi} \geq \tau_{\omega}$, total government revenue $G(a)$ is strictly decreasing in $\bar{w}$ for all $(a, \bar{w})$ combinations in regime II. Put differently, any tax, and minimum wage policy combinations that put an employer in the interior of regime II can be ruled out from the set of government revenue maximizing policy. This is in sharp contrast to the set of poverty alleviating tax policies, which we have just shown to necessarily put employers in regime II (Proposition 4). 
Next, consider instead relatively low minimum wages such that regimes I, III or IV apply, wherein the participation constraint is strictly binding, or, $\omega_{f}^{*}(a)-\tau_{\omega} r^{*}(a)=w_{i} a$, and formal sector expected profits $\pi_{f}^{*}(a)$ are displayed in (16), (23), and (25) respectively for regimes I, III, and IV. Thus:

$$
G(a)=N(a) \theta^{1 /(1-\beta)}\left(\frac{\pi_{f}^{*}(a)}{c_{f}}\right)^{\beta /(1-\beta)}\left(a\left(1-w_{i}\right)-\pi_{f}^{*}(a)\right)
$$

Observe that changes in formal employer profits impact government revenue in two distinctive, and opposite directions. First, raising $\pi_{f}^{*}(a)$ decreases the incidence of informality through $\alpha^{*}(a)=$ $\theta^{1 /(1-\beta)}\left(\frac{\pi_{f}^{*}(a)}{c_{f}}\right)^{\beta /(1-\beta)}$. Second, and going in opposite direction, a higher $\pi_{f}^{*}(a)$ necessarily requires lowering the government revenue per employer $a\left(1-w_{i}\right)-\pi_{f}^{*}(a)$. On balance, total government revenue is maximized by choice of $\pi_{f}^{*}(a)$ satisfying:

$$
\pi_{f}^{*}(a)=\beta a\left(1-w_{i}\right)
$$

so that profit per formal employer is a fraction $\beta$ of the profit per formal employer in the absence of any taxes or minimum wage $a\left(1-w_{i}\right)$. One way to exactly achieve this level of profit is summarized in the following proposition:

Proposition 5 A flat tax reform at minimal minimum wage protection maximizes government revenue $G(a)$. This is accomplished by setting

$$
\bar{w}=0, \quad \tau_{\pi}=\tau_{\omega}=(1-\beta)\left(1-w_{i}\right) .
$$

A zero minimum wage (regime I, or IV) reflects the government's desire to raise revenue, rather than to alleviate poverty. Next, by removing the tax gap, and thus by setting $\delta=0$, regime IV (where $\left.a<\delta /\left(1-\tau_{\omega}-w_{i}\right)=0\right)$ vanishes, and as such all formal employers of workers with $a>0$ report positive profits. With regime I remaining, setting $\delta=0$ also removes any incentives on the part of formal employers to evade taxes evaluated at $\bar{w}=0$ since $r^{*}(a)-\omega_{f}^{*}(a)=\delta$ from (15) for regime I.

To balance the role of the uniform tax rate $\tau_{\pi}=\tau_{\omega}$ on tax revenue per formal employer, and the incidence of informality, the optimal tax rate is set at $(1-\beta)\left(1-w_{i}\right)$ with two considerations in mind. ${ }^{16}$ First, the higher the elasticity of employer entry on job creation $\beta=d \log \Phi(a) / d \log M(a)$, the lower the tax rate will be. Meanwhile, the higher the productivity of informal sector workers relative to formal sector workers $w_{i}$, the lower the tax rate should be.

\footnotetext{
${ }^{16}$ It can also be verified that evaluated at this optimal tax rate $(1-\beta)\left(1-w_{i}\right)$, the post-tax net output of a formal sector worker exceeds that of an informal sector worker, consistent with our assumption that $1-\tau_{\omega}-w_{i}>0$ throughout this paper.
} 


\section{Conclusion}

In this paper, we study the impacts of tax and minimum wage reforms on the incidence of informality, as measured by the extent of minimum wage non-compliance, the extent of tax evasion, and the size of the informal workforce. These measures are based on two distinctive perspectives on informality, associated with labor standard compliance, and tax compliance. The model we propose offers a list of empirically relevant observations and testable hypotheses, featuring (i) the endogenous distinction between firm-level reported wage distribution and actual wage distribution, (ii) the complementarity of tax enforcement on minimum wage enforcement, (iii) the impact that minimum wage reform has on tax and minimum wage compliance, and (iv) the impact that tax policy reform has on tax and minimum wage compliance.

The paper concludes with a look at the design of optimal minimum wage and tax policies, given the objectives of tax revenue minimization, and poverty alleviation among workers. For example, we provide conditions under which a tax reform is consistent with the objective of tax revenue minimization. At the same time, we also offer an optimal minimum wage and tax policy formula consistent with the objective of poverty alleviation. In each case, we highlight the role of the strength of the tax enforcement regime on the optimal tax and minimum wage policy formula.

This paper is a first attempt at analyzing the role of minimum wage and tax policy reforms jointly on minimum wage and tax compliance. Many possible routes for future research remain. For example, while we highlight the role of tax enforcement in this paper, ample opportunities for extension of the basic framework by introducing a combination of tax and minimum wage enforcement remain. In addition, in the tradition of the theory of tax enforcement, the risk attitudes of the employers naturally matter. The introduction of risk aversion, for example, into our basic model is a promising avenue for future work. Finally, in our optimal policy formulation, we have taken the strength of tax enforcement and minimum wage enforcement as given. An extension of the model to allow for endogenous tax and minimum wage enforcement regimes will also be of real interest in efforts to better understand the various nuances of tax and minimum wage policies on informality.

\section{Appendix A}

In this appendix, we verify that for any $\left(\omega_{f}, r\right)$ pair such that neither of the two constraints bind, $\omega_{f}>w_{i} a+\tau_{\omega} r$ and $r>\bar{w}$, an alternative pairing $\left(\omega_{f}^{\prime}, r^{\prime}\right)$ satisfying the a binding participation can be found that raises expected profit, $a-\omega_{f}-\tau_{\pi}(a-r)-\bar{\phi} \bar{p}\left(r-\omega_{f}\right)^{2}<a-\omega_{f}-\tau_{\pi}\left(a-r^{\prime}\right)-\bar{\phi} \bar{p}\left(r^{\prime}-\omega_{f}^{\prime}\right)^{2}$. 
To see this, note that by adding and subtracting $\left(\tau_{\pi}-\tau_{\omega}\right)\left(r-\omega_{f}\right) /\left(1-\tau_{\omega}\right)$ and rearranging terms,

$$
\begin{aligned}
a-\omega_{f}-\tau_{\pi}(a-r)-\bar{\phi} \bar{p}\left(r-\omega_{f}\right)^{2}= & \frac{1-\tau_{\pi}}{1-\tau_{\omega}}\left(a\left(1-\tau_{o}\right)-\omega_{f}+r \tau_{\omega}\right)+\bar{\phi} \bar{p}\left(\frac{\tau_{\pi}-\tau_{\omega}}{2 \bar{\phi} \bar{p}\left(1-\tau_{\omega}\right)}\right)^{2} \\
& -\bar{\phi} \bar{p}\left(\frac{\tau_{\pi}-\tau_{\omega}}{2 \bar{\phi} \bar{p}\left(1-\tau_{\omega}\right)}-\left(r-\omega_{f}\right)\right)^{2} \\
\leq & \frac{1-\tau_{\pi}}{1-\tau_{\omega}}\left(a\left(1-\tau_{\omega}\right)-\omega_{f}+r \tau_{\omega}\right) \\
< & \frac{1-\tau_{\pi}}{1-\tau_{\omega}}\left(a\left(1-\tau_{\omega}-w_{i}\right)\right) \\
= & a-\omega_{f}^{\prime}-\tau_{\pi}(a-r)-\bar{\phi} \bar{p}\left(r^{\prime}-\omega_{f}^{\prime}\right)^{2}
\end{aligned}
$$

where $\omega_{f}^{\prime}=w_{i} a+r^{\prime} \tau_{\omega}$ from $(\mathrm{I}), r^{\prime}=\frac{w_{i} a+\delta}{1-\tau_{\omega}}$, and $\delta=\left(\tau_{\pi}-\tau_{\omega}\right) /\left(2 \bar{\phi} \bar{p}\left(1-\tau_{\omega}\right)\right)$.

\section{References}

Albrecht, James, Lucas Navarro, and Susan Vronman. 2009. "The Effects of Labor Market Policies in an Economy with an Informal Sector,” —it Economic Journal 119: 1105 - 1129.

Almeida, Rita K. and Pedro Carneiro. 2011. "Enforcement of Labor Regulation and Informality," IZA Discussion Papers 5902.

Allingham, M. G., and A. Sandmo. 1972. "Income Tax Evasion: A Theoretical Analysis," Journal of Public Economics 1(3-4): 323-338.

Amaral, P. S. and E. Quintin. 2006. "A Competitive Model of the Informal Sector," Journal of Monetary Economics 53(7): 1541-1553.

Andreoni, J., B. Erard and J. Feinstein. 1998. "Tax Compliance," Journal of Economic Literature 36(2): 818-860.

Ashenfelter, O. and Smith, R. S. (1979). "Compliance with the Minimum Wage Law," Journal of Political Economy, vol. 87(2): 333-50.

Baanante, M. J. 2004. "Minimum Wage Effects under Endogenous Compliance: Evidence from Peru," Económica Vol. L(1-2): 85-123.

Basu, A. K., N. H. Chau and R. Kanbur. 2011. "Contractual Dualism, Market Power and Informality." CEPR Discussion Paper 8485.

Basu, A. K., N. H. Chau and R. Kanbur. 2010. "Turning a Blind Eye: Costly Enforcement, Credible Commitment and Minimum Wage Laws," Economic Journal 120: 244-269.

Bosch, Mariano and William F. Maloney. 2010. "Comparative Analysis of Labor Market Dynamics using Markov Processes: An Application to Informality," Labour Economics 17(4): 621-631. 
Chandra, V. and M. A. Khan. 1993. "Foreign Investment in the Presence of an Informal Sector," Economica 60: 79-103.

Card, D. and Krueger, A. B. (1995). Myth and Measurement: The New Economics of the Minimum Wage, Princeton: Princeton University Press.

Chong, Alberto, Jose Galdo and Jaime Saavedra. 2008. "Informality and Productivity in the Labor Market in Peru," Journal of Economic Policy Reform 11 (4): 229-245.

Cobham, A. 2005. "Tax Evasion, Tax Avoidance, and Development Finance," Queen Elisabeth House Working Paper No. 129.

Cowell, F. (1990). Cheating the Government: The Economics of Evasion. MIT Press.

de Paula, A. and J. Scheinkman. 2010. "Value Added Taxes, China Effects and Informality," American Economic Journal: Macroeconomics 2: 195-221.

de Soto, H. 1989. The Other Path. New York: Basic Books.

Djankov, S., R. La Porta, F. Lopez-de-Silanes, and A. Shleifer. 2002. "The Regulation of Entry," Quarterly Journal of Economics 117 (1): 137.

Djankov, S., Lieberman, I., Mukherjee, J. and Nenova, T. 2003. "Going Informal: Benefits and Costs," in B. Belev (ed.), The Informal Economy in the EU Accession Countries: Size, Scope, Trends and Challenges to the Process of EU Enlargement, Sofia: CSD, pp. 63-80.

Doeringer, P. B. and M. J. Piore. 1971. Internal Labor Markets and Manpower Analysis, Lexington, MA: Heath.

Fei, J. C. H. and G. Ranis. 1964. Development of the Labor Surplus Economy, Homewood, IL: Irwin. Fields, G. 1975. "Rural Urban Migration, Urban Unemployment and Underemployment, and Job Search Activity in LDCs," Journal of Development Economics 2(2): 165 - 187.

Feige, E. L. 1989. The Underground Economies: Tax Evasion and Information Distortion, Cambridge: Cambridge University Press.

Friedman, E., S. Johnson,. D. Kaufmann, and P. Zoido-Lobatón. 2000. "Dodging the Grabbing Hand: The Determinants of Unofficial Activity in 69 Countries." Journal of Public Economics 76: 45993.

Fuest, C. and N. Riedel. 2009. "Tax Evasion, Tax Avoidance and Tax Expenditures in Developing Countries: A Review of the Literature," Report prepared for the UK Department for International Development. 
Fugazza, Marco, and Jean-Francois Jacques. 2004. "Labor Market Institutions, Taxation and the Underground Economy," Journal of Public Economics 88 (1-2): 395-418.

Gabrieli, T., A. F. Galvao Jr. and G. V. Montes-Rojas. 2011. "Who Benefits from Reducing The Cost of Formality? Quantile Regression Discontinuity Analysis." Paper Presented at the IZA/World Bank Workshop: Institutions and Informal Employment in Emerging and Transition Economics. IZA-Bonn.

Gindling, T. and K. Terrell. 1995. "The Nature of Minimum Wages and their Effectiveness as a Wage Floor in Costa Rica, 1976-1991," World Development 23: 1439-58.

Gindling, T. and K. Terrell. 2006. "Minimum Wages, Globalization and Poverty in Honduras," IZA Discussion Paper: 2497.

Harris, J. E. and M. P. Todaro, M.P. 1970. "Migration, Unemployment and Development: a Two Sectors Analysis," American Economic Review 60: 126-142.

Jonasson, E. 2011. "Government Effectiveness and Regional Variation in Informal Employment." Paper Presented at the IZA/World Bank Workshop: Institutions and Informal Employment in Emerging and Transition Economics. IZA-Bonn.

Jung, Y. H., A. Snow, and G. A. Trandel. 1994. "Tax Evasion and the Size of the Underground Economy," Journal of Public Economics 54: 391-402.

Kesselman, J. R. 1989. "Income Tax Evasion: An Intersectoral Analysis," Journal of Public Economics 38(2): 137-182.

Koettl, J. 2011. "Does Formal Work Pay?" Paper Presented at the IZA/World Bank Workshop: Institutions and Informal Employment in Emerging and Transition Economics. IZA-Bonn.

Lemos, S. 2006. "Minimum Wage Effects in a Developing Country," mimeo, University of Leicester.

Lemos, S. 2004. "The Effects of the Minimum Wage in the Formal and Informal sectors in Brazil," IZA Discussion Paper no. 1089.

Loayza, N. 1996. "The Economics of the Informal Sector: A Simple Model and Some Empirical Evidence from Latin America," Carnegie-Rochester Conference Series on Public Policy 45: 129-162.

Loayza, N., L. Servén, and A. M. Oviedo. 2005. "The Impact of Regulation on Growth and InformalityCross-Country Evidence," World Bank Policy Research Working Paper WPS 3623. Maloney, W. 2004. "Informality Revisited," World Development 32(7): 1159 - 1178. 
Maloney, W. and Nunez, J. 2004. 'Measuring the impact of minimum wages: evidence from Latin America', in (J. Heckman and C. Pagès eds.) Law and Employment. Lessons from Latin America and the Caribbean. Cambridge, MA: NBER.

OECD. 2009. Is Informal Normal? Towards More and Better Jobs. Paris: OECD.

Perry, G., W. Maloney, O. Arias, P. Pajnzylber, A. Mason and J. Saavera-Chanduvi. 2007. Informality: Exit and Exclusion. Washington, D.C.: The World Bank.

PricewaterhouseCoopers. 2011. Worldwide Tax Summaries.

http://www.pwc.com/gx/en/ worldwide-tax-summaries/index.jhtml, accessed: August, 2011

Saavedra, J., and A. Chong. 1999. "Structural Reforms, Institutions and Earnings: Evidence from the Formal and Informal Sectors in Urban Peru," Journal of Development Studies 35 (4): 95116.

Saget, C. 2008. "Fixing Minimum Wage Levels in Developing Countries: Common Failures and Remedies," International Labour Review 147 (1): 2542.

Schneider, F. 2005. "Shadow Economies around the World: What Do We Really Know?" European Journal of Political Economy 21 (3): 598642.

Schneider, F. 2011. "The Shadow Economy and Shadow Economy Labor Force: What Do We (Not) Know?" IZA Discussion Paper 5769.

Schneider, F., and Enste, D. 2000. "Shadow economies: Size, Causes, and Consequences," Journal of Economic Literature 38(1): 77-114.

Slonimczyk, F. 2011. "The Effect of Taxation and Informal Employment: Evidence from the Russian Flat Tax Reform." Paper Presented at the IZA/World Bank Workshop: Institutions and Informal Employment in Emerging and Transition Economics. IZA-Bonn.

Stiglitz, J. E. 1974. "Alternative Theories of Wage Determination and Unemployment in LDC's: The Labor Turnover Model," Quarterly Journal of Economics 88(2): 194-227.

Straub, S. 2005. "Informal Sector: The Credit Market Channel," Journal of Development Economics $78(2): 299-321$.

Strobl, E. and F. Walsh. 2001. "Minimum Wage and Compliance: the Case of Trinidad and Tobago," Economic Development and Cultural Change, vol. 51(2), 427-50.

Tanzi, V. 1980. "Underground Economy and Tax Evasion in the United States: Estimates and Implications," Banca Nazionale del Lavoro Quarterly Review 32: 427-453. 
Tanzi, V. 1999. "Uses and Abuses of Estimates of the Underground Economy," Economic Journal 109: F338-F347.

Tonin, M. 2011. "Minimum Wage and Tax Evasion: Theory and Evidence," IZA Discussion Paper No. 5660 .

Weil, D. 2004. "Compliance with the Minimum Wage: Can Government Make a Difference," Harvard Center for Textile and Apparel Research Working Paper HR 05.

World Bank. 2010. Doing Business Project. Availabe at http://www.doingbusiness.org/)

World Bank. 2011. Enterprise Surveys. Available at https://www.enterprisesurveys.org/

Yaniv, G. 1988. "Withholding and Non-withheld Tax Evasion," Journal of Public Economics 35: 183-204.

Yaniv, G. 1990. "Tax Evasion under Differential Taxation," Journal of Public Economics 43: 327 -337 .

Yitzhaki, S. 1974. "A Note on 'Income Tax Evasion: A Theoretical Analysis'," Journal of Public Economics 3(2): 201-202. 
Table 1: Informality, Labor Standards Compliance

\begin{tabular}{|c|c|c|c|c|c|}
\hline \multirow[t]{3}{*}{ Country } & \multicolumn{5}{|c|}{ Alternative Measures of Informality } \\
\hline & \multicolumn{2}{|c|}{$\begin{array}{l}\text { I. Share of workers not } \\
\text { covered by social } \\
\text { security contributions }\end{array}$} & \multirow{2}{*}{$\begin{array}{c}\begin{array}{c}\text { II. Share of workers } \\
\text { without an } \\
\text { employment contract }\end{array} \\
2006\end{array}$} & \multicolumn{2}{|c|}{$\begin{array}{l}\text { III. Non-coverage by } \\
\text { social protection }\end{array}$} \\
\hline & 2007 & 2008 & & 1995-99 & $2000-07$ \\
\hline Algeria & & & & 42.7 & 41.3 \\
\hline Argentina & & & & 53.3 & - \\
\hline Austria & 35.4 & 34.5 & 10 & & \\
\hline Belgium & 38.8 & 36.2 & 7 & & \\
\hline Bolivia & & & & 63.5 & - \\
\hline Brazil & & & & 60 & 51.1 \\
\hline Chad & & & & 95.2 & - \\
\hline Chile & & & & 35.8 & - \\
\hline Colombia & & & & 38.4 & - \\
\hline Costa Rica & & & & 44.3 & - \\
\hline Czech Republic & 40.8 & 40.4 & 2 & & \\
\hline Denmark & & & 12 & & \\
\hline Dominican Republic & & & & 47.6 & - \\
\hline Ecuador & & & & 53.5 & - \\
\hline Egypt, Arab Rep. & & & & 55.2 & 45.9 \\
\hline El Salvador & & & & 56.6 & - \\
\hline Estonia & 34.6 & 33.9 & 5 & & \\
\hline Finland & 23.0 & 23.5 & 1 & & \\
\hline France & 51.9 & - & 8 & & \\
\hline Germany & & & 4 & & \\
\hline Greece & 37.1 & 37.3 & 39 & & \\
\hline Guinea & & & & 86.7 & - \\
\hline Haiti & & & & 92.6 & - \\
\hline Honduras & & & & 58.2 & - \\
\hline Hungary & 40.6 & 42.4 & 4 & & \\
\hline Iceland & 13.4 & 13.3 & 26 & & \\
\hline India & & & & 83.4 & - \\
\hline Indonesia & & & & 77.9 & - \\
\hline Ireland & 39.8 & 40.3 & 39 & & \\
\hline Israel & & & 38 & & \\
\hline Italy & 40.0 & 39.3 & & & \\
\hline Iran & & & & - & 48.8 \\
\hline Kenya & & & & 71.6 & - \\
\hline Kyrgyz Republic & & & & - & 44.4 \\
\hline Lebanon & & & & - & 51.8 \\
\hline Luxembourg & 34.6 & 32.6 & 6 & & \\
\hline Mali & & & & 94.1 & 81.8 \\
\hline Mexico & & & & 59.4 & 50.1 \\
\hline Moldova & & & & - & 21.5 \\
\hline Morocco & & & & 44.8 & 67.1 \\
\hline Netherlands & 17.7 & 21.6 & 9 & & \\
\hline Norway & 12.2 & 13.2 & 11 & & \\
\hline Pakistan & & & & 64.6 & - \\
\hline Panama & & & & 37.6 & 49.4 \\
\hline Paraguay & & & & 65.5 & - \\
\hline Peru & & & & - & 67.9 \\
\hline Philippines & & & & 72 & - \\
\hline Poland & 65.3 & 57.0 & 6 & & \\
\hline Portugal & 35.1 & 38.5 & 15 & & \\
\hline Romania & & & & 5.4 & 22 \\
\hline Russian Federation & & & 7 & - & 8.6 \\
\hline
\end{tabular}


Table 1: Informality, Labor Standards Compliance

\begin{tabular}{|c|c|c|c|c|c|}
\hline \multirow[t]{3}{*}{ Country } & \multicolumn{5}{|c|}{ Alternative Measures of Informality } \\
\hline & \multicolumn{2}{|c|}{$\begin{array}{l}\text { I. Share of workers not } \\
\text { covered by social } \\
\text { security contributions }\end{array}$} & \multirow{2}{*}{$\begin{array}{c}\begin{array}{c}\text { II. Share of workers } \\
\text { without an } \\
\text { employment contract }\end{array} \\
2006\end{array}$} & \multicolumn{2}{|c|}{$\begin{array}{l}\text { III. Non-coverage by } \\
\text { social protection }\end{array}$} \\
\hline & 2007 & 2008 & & 1995-99 & $2000-07$ \\
\hline Slovak Republic & 39.1 & 38.5 & 3 & & \\
\hline Slovenia & 24.7 & 25.2 & 11 & & \\
\hline South Africa & & & & - & 50.6 \\
\hline Spain & 41.5 & 41.4 & 10 & & \\
\hline Sweden & 22.7 & 22.0 & 2 & & \\
\hline Switzerland & & & 5 & & \\
\hline Syrian Arab Republic & & & & 42.9 & 30.7 \\
\hline Thailand & & & & 51.5 & - \\
\hline Turkey & & & 44 & 30.9 & 33.2 \\
\hline Tunisia & & & & 47.1 & 35 \\
\hline United Kingdom & & & 22 & & \\
\hline Venezuela, R.B. & & & & 46.9 & 49.4 \\
\hline West Bank and Gaza & & & & - & 43.4 \\
\hline Yemen, Rep. & & & & - & 51.1 \\
\hline
\end{tabular}

${ }^{1}$ Measure (I) is based on EU-SILC 2007 and 2008, re-produced from Schneider (2011), measure (II) is based on the European Social Survey 2008, re-produced from Schneider (2011) and measure (III) is taken from OECD (2009) tabulations from national labor force surveys where informality is defined as non-coverage by social protection. 
Table 2: Informality, Enterprise Surveys

\begin{tabular}{|c|c|c|c|c|}
\hline \multirow{2}{*}{ Country (Year) } & \multicolumn{4}{|c|}{ Alternative Measures of Informality } \\
\hline & $\begin{array}{l}\text { I. \% of firms } \\
\text { which report } \\
\text { too few sales }\end{array}$ & $\begin{array}{c}\text { II. \% of firms } \\
\text { competing with } \\
\text { unregistered/informal } \\
\text { firms }\end{array}$ & $\begin{array}{l}\text { III. \% of firms } \\
\text { registered when } \\
\text { starting } \\
\text { operations }\end{array}$ & $\begin{array}{l}\text { IV. Number of years } \\
\text { firm operated } \\
\text { without } \\
\text { registration }\end{array}$ \\
\hline Afghanistan (2008) & - & 45.88 & 88.01 & 1.8 \\
\hline Albania (2007) & - & 52.56 & 89.35 & 0.26 \\
\hline Algeria (2007) & - & 66.84 & 98.32 & 0.04 \\
\hline Angola (2010) & - & 41.25 & 62.65 & 1.12 \\
\hline Argentina (2010) & - & 68.2 & 92.35 & 0.87 \\
\hline Armenia (2009) & - & 44.57 & 96.23 & 0.14 \\
\hline Azerbaijan (2009) & - & 40.71 & 85.12 & 4.73 \\
\hline Bangladesh (2007) & - & 46.62 & - & - \\
\hline Belarus (2008) & - & 50.43 & 98.48 & 2.9 \\
\hline Benin (2009) & - & 77.25 & 87.93 & 0.55 \\
\hline Bhutan (2009) & - & 19.92 & 99.05 & 0.08 \\
\hline Bolivia (2010) & - & 80.51 & 72.43 & 4.25 \\
\hline Bosnia and Herzegovina (2009) & - & 46.48 & 98.6 & 0.16 \\
\hline Botswana (2010) & - & 54.64 & 93.94 & 0.16 \\
\hline Brazil (2009) & - & 55.02 & 95.78 & 0.48 \\
\hline Bulgaria (2009) & - & 54.11 & 98.48 & 0.08 \\
\hline Burkina Faso (2009) & 26.45 & 74.95 & 77.74 & 1.01 \\
\hline Burundi (2006) & 42.73 & 60.3 & - & - \\
\hline Cambodia (2007) & 78.11 & - & 87.45 & 0.69 \\
\hline Cameroon (2009) & 70.38 & 90.11 & 82.06 & 0.63 \\
\hline Cape Verde (2009) & - & 44.54 & 81.25 & 1.96 \\
\hline Chad (2009) & - & 89.8 & 77.13 & 1.23 \\
\hline Chile (2010) & - & 55.84 & 96.05 & 0.2 \\
\hline China (2003) & 49.45 & - & - & - \\
\hline Colombia (2010) & - & 70.93 & 94.27 & 0.47 \\
\hline Congo, Dem. Rep. (2010) & - & 89.96 & 61.86 & 1.87 \\
\hline Congo, Rep. (2009) & 90.02 & 69.65 & 84.28 & 0.27 \\
\hline Costa Rica (2010) & - & 70.36 & 80.84 & 1.04 \\
\hline Cte d'Ivoire (2009) & 68.06 & 73.6 & 56.37 & 0.48 \\
\hline Croatia (2007) & - & 31.66 & 98.07 & 0.03 \\
\hline Czech Republic (2009) & - & 42.87 & 98.04 & 0.08 \\
\hline Dominican Republic (2005) & 73.63 & - & - & - \\
\hline Ecuador (2010) & - & 65.72 & 85.1 & 0.65 \\
\hline Egypt, Arab Rep. (2008) & 30 & 46.68 & - & - \\
\hline El Salvador (2010) & - & 65.24 & 75.67 & 1.1 \\
\hline Eritrea (2009) & - & 28.16 & 100 & 0 \\
\hline Estonia (2009) & - & 26.32 & 97.39 & 0.06 \\
\hline Ethiopia (2006) & 51.6 & - & - & - \\
\hline Fiji (2009) & - & 39.6 & 93.48 & 1.15 \\
\hline Gabon (2009) & 64.83 & 75.96 & 63.73 & 0.73 \\
\hline Gambia, the (2006) & 88.05 & 60.34 & - & - \\
\hline Georgia (2008) & - & 52.23 & 99.55 & 0.42 \\
\hline Germany (2005) & - & - & - & - \\
\hline Ghana (2007) & 59.2 & 69.13 & 66.44 & 2.17 \\
\hline Greece (2005) & 53.19 & - & - & - \\
\hline Guatemala (2010) & - & 69.84 & 89.98 & 0.59 \\
\hline Guinea (2006) & 95.37 & 62.8 & - & - \\
\hline Guinea-Bissau (2006) & 68.19 & 53.7 & - & - \\
\hline Guyana, CR (2004) & 74.36 & - & - & - \\
\hline Honduras (2010) & - & 63.17 & 81.29 & 0.86 \\
\hline Hungary (2009) & - & 49 & 100 & 0 \\
\hline
\end{tabular}


Table 2: Informality, Enterprise Surveys

\begin{tabular}{|c|c|c|c|c|}
\hline \multirow[t]{2}{*}{ Country (Year) } & \multicolumn{4}{|c|}{ Alternative Measures of Informality } \\
\hline & $\begin{array}{l}\text { I. \% of firms } \\
\text { which report } \\
\text { too few sales }\end{array}$ & $\begin{array}{c}\text { II. \% of firms } \\
\text { competing with } \\
\text { unregistered/informal } \\
\text { firms }\end{array}$ & $\begin{array}{l}\text { III. \% of firms } \\
\text { registered when } \\
\text { starting } \\
\text { operations }\end{array}$ & $\begin{array}{l}\text { IV. Number of years } \\
\text { firm operated } \\
\text { without } \\
\text { registration }\end{array}$ \\
\hline India (2006) & 59.24 & - & - & - \\
\hline Indonesia (2009) & - & 65.09 & 29.1 & 2.43 \\
\hline Ireland (2005) & 28.78 & - & - & - \\
\hline Jamaica (2005) & 28.77 & - & - & - \\
\hline Jordan (2006) & 12.95 & - & - & - \\
\hline Kazakhstan (2009) & - & 36.89 & 97.37 & 0.04 \\
\hline Kenya (2007) & 60.54 & - & - & - \\
\hline Korea, Rep. (2005) & 43.65 & - & - & - \\
\hline Kosovo (2009) & - & 64.07 & 89.23 & 0.23 \\
\hline Kyrgyz Republic (2009) & - & 67.46 & 95.94 & 4.3 \\
\hline Lao PDR (2009) & - & 12.82 & 93.53 & 0.17 \\
\hline Latvia (2009) & - & 41.67 & 98.49 & 0.12 \\
\hline Lebanon (2009) & 34.98 & - & 97.63 & 0.28 \\
\hline Lesotho (2009) & - & 59.6 & 86.8 & 0.63 \\
\hline Liberia (2009) & 97.32 & 66.21 & 73.81 & 0.63 \\
\hline Lithuania (2009) & - & 50.11 & 97.1 & 0.25 \\
\hline Macedonia, FYR (2009) & - & 73.89 & 99.24 & 0.01 \\
\hline Madagascar (2009) & 35.61 & 62.29 & 97.45 & 0.09 \\
\hline Malawi (2009) & - & 77.84 & 78.58 & 0.57 \\
\hline Malaysia (2007) & - & - & 52.97 & 0 \\
\hline Mali (2010) & - & 75.38 & 79.22 & 0.51 \\
\hline Mauritania (2006) & 82.5 & 65.16 & - & - \\
\hline Mauritius (2009) & 36.25 & 50.95 & 84.17 & 1.54 \\
\hline Mexico (2006) & 57.65 & 69.67 & 94.08 & 0.1 \\
\hline Micronesia, Fed. Sts. (2009) & - & 41.11 & 96.87 & 0.16 \\
\hline Moldova (2009) & - & 46.46 & 97.86 & 0.11 \\
\hline Mongolia (2009) & - & 43.04 & 90.11 & 2.49 \\
\hline Montenegro (2009) & - & 27.26 & 95.47 & 0.21 \\
\hline Morocco (2007) & - & 47.68 & 86.02 & 0.21 \\
\hline Mozambique (2007) & 73.1 & 75.45 & 85.86 & 0.6 \\
\hline Namibia (2006) & 45.48 & 33.09 & - & - \\
\hline Nepal (2009) & - & 49.37 & 93.96 & 0.33 \\
\hline Nicaragua (2010) & - & 62.61 & 74.03 & 2.02 \\
\hline Niger (2009) & - & 85.98 & 90.51 & 0.54 \\
\hline Nigeria (2007) & 68 & 60.07 & - & - \\
\hline Oman (2003) & 42.46 & - & - & - \\
\hline Pakistan (2007) & 7.57 & 12.45 & - & - \\
\hline Panama (2010) & - & 51.4 & 99.74 & 0.01 \\
\hline Paraguay (2010) & - & 75.28 & 98.71 & 0.25 \\
\hline Peru (2010) & - & 68.59 & 82.63 & 0.73 \\
\hline Philippines (2009) & - & 37.52 & 97.53 & 0.53 \\
\hline Poland (2009) & - & 32.73 & 99.25 & 0.02 \\
\hline Portugal (2005) & 37.25 & - & - & - \\
\hline Romania (2009) & - & 35.14 & 98.71 & 0.11 \\
\hline Russian Federation (2009) & - & 32.23 & 94.68 & 0.77 \\
\hline Rwanda (2006) & 28.9 & 47.07 & - & - \\
\hline Samoa (2009) & - & 63.56 & 88.36 & 0.58 \\
\hline Senegal (2007) & 21.63 & 74.11 & 78.86 & 0.95 \\
\hline Serbia $(2009)$ & - & 53.62 & 95.02 & 0.19 \\
\hline Sierra Leone (2009) & 81.92 & 80.34 & 89.22 & 0.86 \\
\hline Slovak Republic (2009) & - & 40.34 & 100 & 0 \\
\hline Slovenia (2009) & - & 27.44 & 99.85 & 0.01 \\
\hline
\end{tabular}


Table 2: Informality, Enterprise Surveys

\begin{tabular}{|c|c|c|c|c|}
\hline \multirow[t]{2}{*}{ Country (Year) } & \multicolumn{4}{|c|}{ Alternative Measures of Informality } \\
\hline & $\begin{array}{l}\text { I. \% of firms } \\
\text { which report } \\
\text { too few sales }\end{array}$ & $\begin{array}{l}\text { II. \% of firms } \\
\text { competing with } \\
\text { unregistered/informal } \\
\text { firms }\end{array}$ & $\begin{array}{l}\text { III. \% of firms } \\
\text { registered when } \\
\text { starting } \\
\text { operations }\end{array}$ & $\begin{array}{l}\text { IV. Number of years } \\
\text { firm operated } \\
\text { without } \\
\text { registration }\end{array}$ \\
\hline South Africa (2007) & 40.3 & 45.32 & 91.03 & 0.26 \\
\hline Spain (2005) & 18.33 & - & - & - \\
\hline Sri Lanka (2004) & 41.97 & - & - & - \\
\hline Swaziland (2006) & 74.57 & 39.72 & - & - \\
\hline Syrian Arab Republic (2009) & 57.06 & 52.57 & - & - \\
\hline Tajikistan (2008) & - & 35.31 & 92.74 & 6.78 \\
\hline Tanzania (2006) & 71.03 & 66.85 & - & - \\
\hline Thailand (2006) & - & - & - & - \\
\hline Timor-Leste (2009) & - & 66.4 & 91.79 & 0.67 \\
\hline Togo $(2009)$ & - & 80.49 & 75.82 & 1.15 \\
\hline Tonga (2009) & - & 86.77 & 93.54 & 0.25 \\
\hline Turkey (2008) & - & 52.36 & 94.05 & 0.42 \\
\hline Uganda (2006) & 74.49 & 73.11 & - & - \\
\hline Ukraine (2008) & - & 48.48 & 95.76 & 0.92 \\
\hline Uruguay (2010) & - & 67.66 & 94.61 & 0.64 \\
\hline Uzbekistan (2008) & - & 39.17 & 100 & 4.09 \\
\hline Vanuatu (2009) & - & 39.91 & 88.06 & 1.26 \\
\hline Venezuela, R.B. (2010) & - & 29.76 & 95.61 & 0.13 \\
\hline Vietnam (2009) & - & 55.56 & 87.46 & 1.38 \\
\hline West Bank and Gaza (2006) & 25.68 & - & - & - \\
\hline Yemen, Rep. (2010) & 82.33 & 37.16 & 81.69 & 0.82 \\
\hline Zambia (2007) & - & 73.84 & 96.18 & 0.23 \\
\hline
\end{tabular}

1 The four measures give the degree of informality among businesses in 125 countries. The table is re-produced from results based on surveys of more than 120,000 firms by the World Bank (Enterprise Surveys, http://www.enterprisesurveys.org, methodology available from https://www.enterprisesurveys.org/Methodology/).

2 Measure (I) is constructed from the percentage of firms expressing that a typical firm reports less than 100 percent of sales for tax purposes, measure (II) is constructed from the percentage of firms competing against unregistered or informal firms (Question: Does this establishment compete against unregistered or informal firms?), measure (III) is constructed from the percentage of firms formally registered when they started operations in the country (Question: Was this establishment formally registered when it began operations?) and measure (IV) is constructed from the average number of years firms operated without formal registration, computed only for the firms not formally registered when starting operations (Question: In what year did this establishment begin operations? Question: Was this establishment formally registered when it began operations? Question: In what year was this establishment formally registered?). 
Table 3: Taxation

\begin{tabular}{|c|c|c|}
\hline Country & $\begin{array}{l}\text { I. Tax rate on } \\
\text { Profit, } \tau_{\pi}\end{array}$ & $\begin{array}{c}\text { II. Tax rate on } \\
\text { Personal Income, } \tau_{\omega}\end{array}$ \\
\hline Albania & 40.6 & 0 \\
\hline Angola & 53.2 & 0 \\
\hline Antigua and Bermuda & 41.5 & 0 \\
\hline Argentina & 108.2 & 9 \\
\hline Armenia & 40.7 & 10 \\
\hline Australia & 47.9 & 0 \\
\hline Austria & 55.5 & 0 \\
\hline Azerbaijan & 40.9 & 14 \\
\hline Belarus & 80.4 & 12 \\
\hline Belgium & 57 & 25 \\
\hline Bolivia & 80 & 13 \\
\hline Bosnia and Herzegovina & 23 & 10 \\
\hline Botswana & 19.5 & 0 \\
\hline Brazil & 69 & 0 \\
\hline Bulgaria & 29 & 10 \\
\hline Cambodia & 22.5 & 0 \\
\hline Cameroon & 49.1 & 11 \\
\hline Canada & 29.2 & 15 \\
\hline Chile & 25 & 0 \\
\hline China & 63.5 & 5 \\
\hline Colombia & 78.7 & 0 \\
\hline Congo, Dem. Rep. & 339.7 & 3 \\
\hline Congo, Rep. & 65.5 & 1 \\
\hline Costa Rica & 55 & 0 \\
\hline Croatia & 32.5 & 12 \\
\hline Cyprus & 23.2 & 0 \\
\hline Czech Republic & 48.8 & 15 \\
\hline Denmark & 29.2 & 37 \\
\hline Dominican Republic & 40.7 & 0 \\
\hline Ecuador & 35.3 & 0 \\
\hline Egypt, Arab Rep. & 42.6 & 0 \\
\hline El Salvador & 35 & 0 \\
\hline Equatorial Guinea & 59.5 & 0 \\
\hline Estonia & 49.6 & 21 \\
\hline Fiji & 39.3 & 0 \\
\hline Finland & 44.6 & 6.5 \\
\hline France & 65.8 & 0 \\
\hline Gabon & 43.5 & 0 \\
\hline Georgia & 15.3 & 20 \\
\hline Germany & 48.2 & 0 \\
\hline Ghana & 32.7 & 0 \\
\hline Greece & 47.2 & 0 \\
\hline Guatemala & 40.9 & 15 \\
\hline Honduras & 48.3 & 0 \\
\hline Hong Kong SAR, China & 24.1 & 2 \\
\hline Hungary & 53.3 & 16 \\
\hline India & 63.3 & 0 \\
\hline Indonesia & 37.3 & 5 \\
\hline Iraq & 28.4 & 3 \\
\hline Israel & 31.7 & 10 \\
\hline Italy & 68.6 & 23 \\
\hline Jamaica & 50.1 & 0 \\
\hline Japan & 48.6 & 5 \\
\hline Jordan & 31.2 & 7 \\
\hline Kazakhstan & 29.6 & 10 \\
\hline
\end{tabular}


Table 3: Taxation

\begin{tabular}{|c|c|c|}
\hline Country & $\begin{array}{l}\text { I. Tax rate on } \\
\text { Profit, } \tau_{\pi}\end{array}$ & $\begin{array}{c}\text { II. Tax rate on } \\
\text { Personal Income, } \tau_{\omega}\end{array}$ \\
\hline Kenya & 49.7 & 10 \\
\hline Korea, Rep. & 29.8 & 6 \\
\hline Kyrgyz Republic & 57.2 & 10 \\
\hline Lao PDR & 33.7 & 0 \\
\hline Latvia & 38.5 & 25 \\
\hline Lebanon & 30.2 & 2 \\
\hline Lithuania & 38.7 & 0 \\
\hline Luxembourg & 21.1 & 0 \\
\hline Macedonia, FYR & 10.6 & 10 \\
\hline Madagascar & 37.7 & 0 \\
\hline Malawi & 25.1 & 0 \\
\hline Malaysia & 33.7 & 0 \\
\hline Mauritius & 24.1 & 15 \\
\hline Mexico & 50.5 & 1.92 \\
\hline Moldova & 30.9 & 7 \\
\hline Mongolia & 23 & 10 \\
\hline Montenegro & 26.6 & 9 \\
\hline Morocco & 41.7 & 0 \\
\hline Mozambique & 34.3 & 10 \\
\hline Namibia & 9.6 & 0 \\
\hline Netherlands & 40.5 & 33 \\
\hline New Zealand & 34.3 & 10.5 \\
\hline Nicaragua & 63.2 & 0 \\
\hline Nigeria & 32.2 & 5 \\
\hline Norway & 41.6 & 0 \\
\hline Oman & 21.6 & 0 \\
\hline Pakistan & 31.6 & 0.75 \\
\hline Panama & 50.1 & 0 \\
\hline Papua New Guinea & 42.3 & 22 \\
\hline Paraguay & 35 & 8 \\
\hline Peru & 40.2 & 0 \\
\hline Philippines & 45.8 & 5 \\
\hline Poland & 42.3 & 18 \\
\hline Portugal & 43.3 & 11.5 \\
\hline Puerto Rico & 67.7 & 0 \\
\hline Romania & 44.9 & 16 \\
\hline Russian Federation & 46.5 & 13 \\
\hline Saudi Arabia & 14.5 & 0 \\
\hline Senegal & 46 & 0 \\
\hline Serbia & 34 & 10 \\
\hline Singapore & 25.4 & 0 \\
\hline Slovak Republic & 48.7 & 19 \\
\hline Slovenia & 35.4 & 16 \\
\hline South Africa & 30.5 & 18 \\
\hline Spain & 56.5 & 24 \\
\hline Sri Lanka & 64.7 & 4 \\
\hline St. Kitts and Nevis & 52.7 & 0 \\
\hline Swaziland & 36.8 & 20 \\
\hline Sweden & 54.6 & 31 \\
\hline Switzerland & 30.1 & 0 \\
\hline Syrian Arab Republic & 42.9 & 5 \\
\hline Tajikistan & 86 & 8 \\
\hline Tanzania & 45.2 & 0 \\
\hline Thailand & 37.4 & 0 \\
\hline Turkey & 44.5 & 15 \\
\hline
\end{tabular}


Table 3: Taxation

\begin{tabular}{lcc}
\hline Country & $\begin{array}{c}\text { I. Tax rate on } \\
\text { Profit, } \tau_{\pi}\end{array}$ & $\begin{array}{c}\text { II. Tax rate on } \\
\text { Personal Income, } \tau_{\omega}\end{array}$ \\
\hline Uganda & 35.7 & 0 \\
Ukraine & 55.5 & 15 \\
United Arab Emirates & 14.1 & 0 \\
United Kingdom & 37.3 & 20 \\
United States & 46.8 & 10 \\
Uruguay & 42 & 0 \\
Uzbekistan & 95.6 & 10 \\
Venezuela, RB & 52.6 & 6 \\
Vietnam & 33.1 & 5 \\
Zimbabwe & 40.3 & 3 \\
\end{tabular}

${ }^{1}$ Tax rate on profit, $\tau_{\pi}$, measures the amount of taxes and mandatory contributions payable by businesses after accounting for allowable deductions and exemptions as a share of commercial profits. Taxes withheld (such as personal income tax) or collected and remitted to tax authorities (such as value added taxes, sales taxes or goods and service taxes) are excluded. This variable is taken from the World Bank, Doing Business project (http://www.doingbusiness.org/), 2010 figures.

${ }^{2}$ Tax rate on personal income, $\tau_{\omega}$, is the lowest tax on personal income taken from PricewaterhouseCoopers International Limited (PwCIL), Worldwide Tax Summaries, current estimates (August 2011). 
Table 4: The Determinants of Tax Evasion $\left|r^{*}(a)-\omega_{f}^{*}(a)\right|$ in the Four Regimes, assuming $\tau_{\pi}>\tau_{\omega}$.

\begin{tabular}{ccccc} 
& I & II & III & IV \\
\hline & $\delta=\left(\tau_{\pi}-\tau_{\omega}\right) /\left(2 \bar{\phi} \bar{p}\left(1-\tau_{\omega}\right)\right)$ & $1 /(2 \bar{\phi} \bar{p})$ & $\bar{w}\left(1-\tau_{\omega}\right)-w_{i} a$ & $a\left(1-\tau_{\omega}-w_{i}\right)$ \\
\hline$\tau_{\pi}$ & + & 0 & 0 & 0 \\
$\tau_{\omega}$ & - & 0 & - & - \\
$\bar{w}$ & 0 & 0 & + & 0 \\
$\bar{\phi} \bar{p}$ & - & - & 0 & 0 \\
\hline
\end{tabular}

Table 5: The Determinants of Minimum Wage Non-Compliance $\bar{w}\left(1-\tau_{\omega}\right)-\left[\omega_{f}^{*}(a)-\tau_{\omega} r^{*}(a)\right]$ in the Four Regimes.

\begin{tabular}{ccccc} 
& I & II & III & IV \\
\hline & $\bar{w}\left(1-\tau_{\omega}\right)-w_{i} a$ & $1 /(2 \bar{\phi} \bar{p})$ & $\bar{w}\left(1-\tau_{\omega}\right)-w_{i} a$ & $\bar{w}\left(1-\tau_{\omega}\right)-w_{i} a$ \\
\hline$\tau_{\pi}$ & 0 & 0 & 0 & 0 \\
$\tau_{\omega}$ & - & 0 & - & - \\
$\bar{w}$ & + & 0 & + & 0 \\
$\bar{\phi} \bar{p}$ & 0 & - & 0 & 0 \\
\hline
\end{tabular}


Table 6: The Determinants of the Incidence of Informality $1-\alpha^{*}(a)$ in the Four Regimes.

\begin{tabular}{cccccc} 
& I & II & III & IV \\
\hline$\tau_{\pi}$ & + & + & + & 0 \\
$\tau_{\omega}$ & + & 0 & + & + \\
$\bar{w}$ & 0 & + & + & 0 \\
$\bar{\phi} \bar{p}$ & + & + & + & + \\
\hline
\end{tabular}




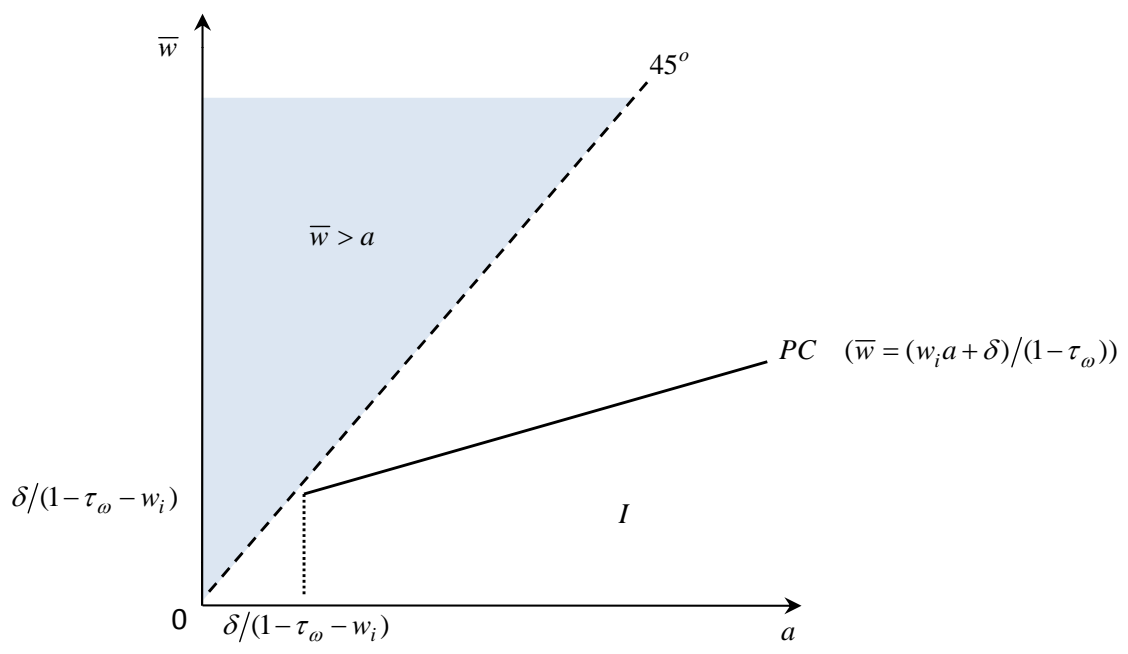

Figure 1a.

Binding Participation Constraint

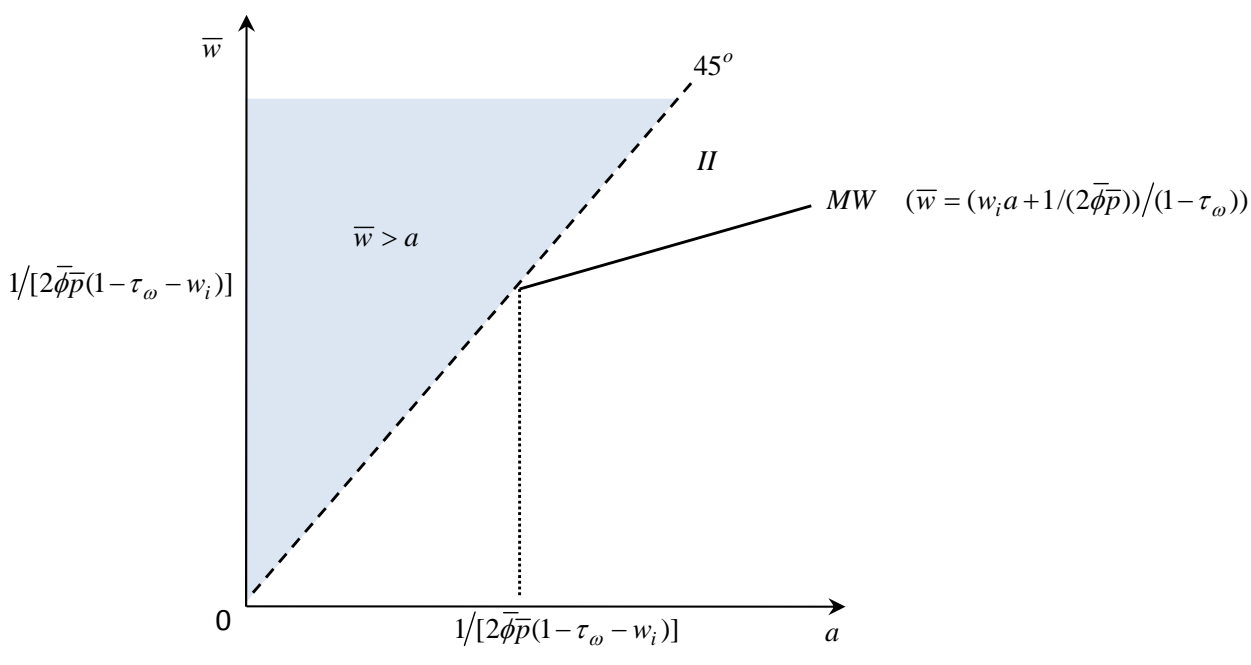

Figure1b.

Binding Minimum Wage Constraint 


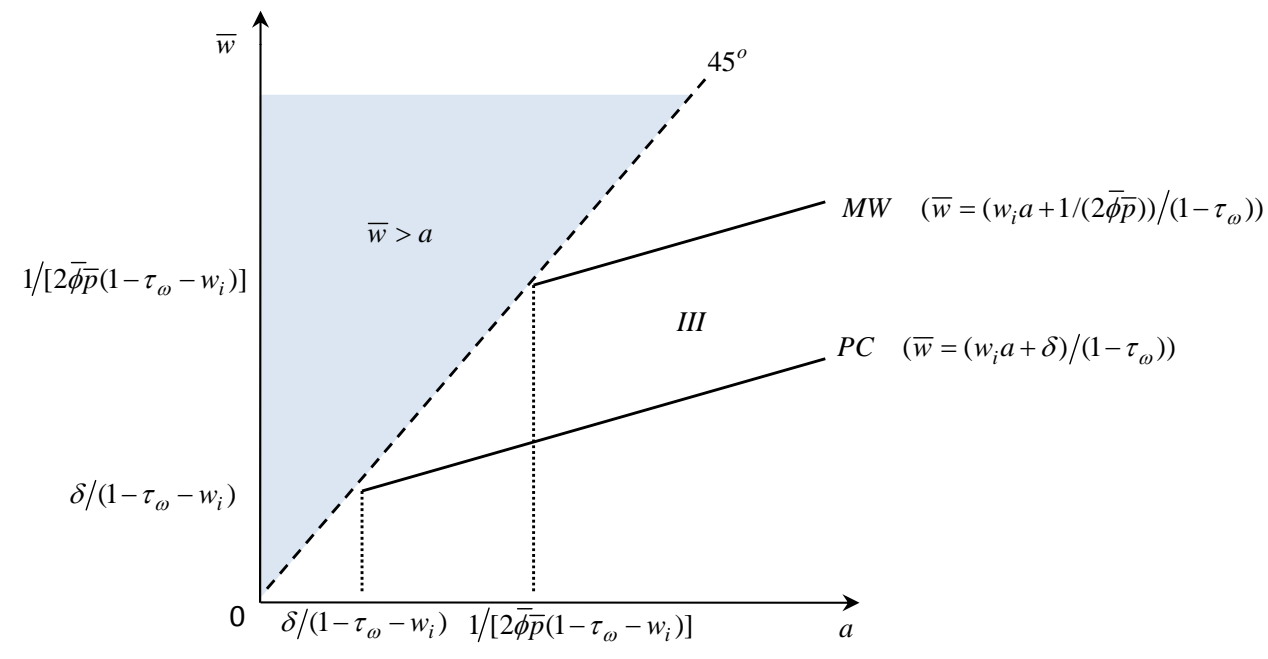

Figure 1c.

Binding Participation and Minimum Wage Constraints

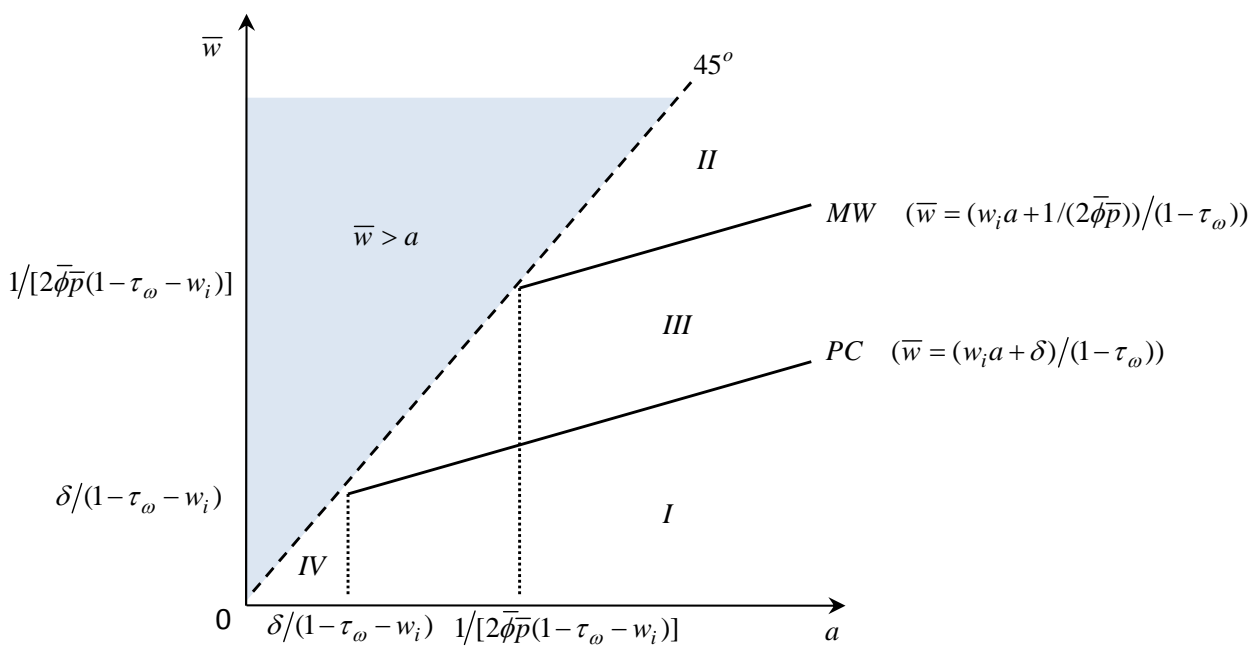

Figure 2.

The Four Regimes 